\title{
Application for a Permit to Operate a Class III Solid Waste Disposal Site at the Nevada Test Site Area 5 Asbestiform Low-Level Solid Waste Disposal Site
}

August 2010

Revision 6

Prepared for the U.S. Department of Energy

National Nuclear Security Administration

Nevada Site Office
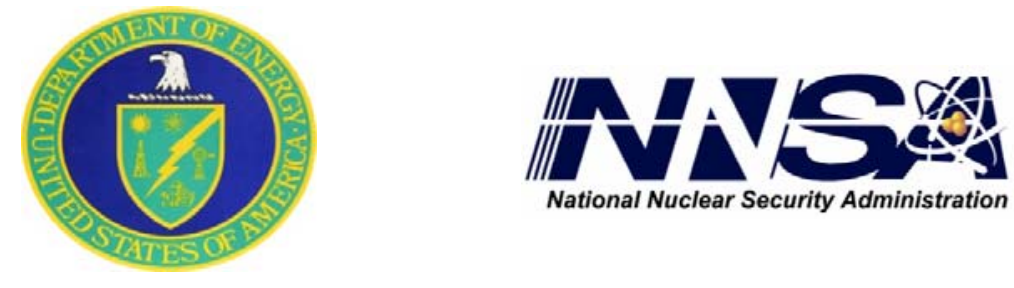

Prepared by

National Security Technologies, LLC

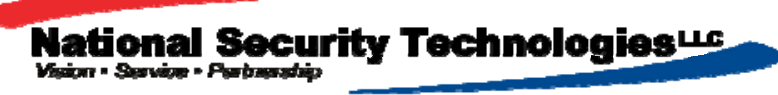




\section{Disclaimer}

Reference herein to any specific commercial product, process, or service by trade name, trademark, manufacturer, or otherwise, does not necessarily constitute or imply its endorsement, recommendation, or favoring by the U.S. Government or any agency thereof. 


\section{Contents}

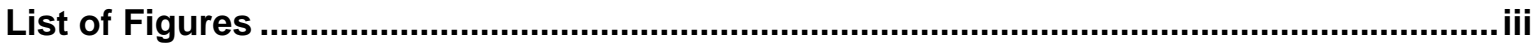

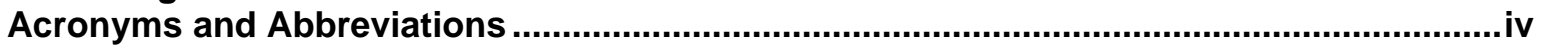

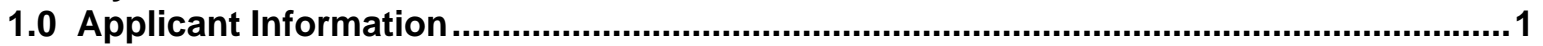

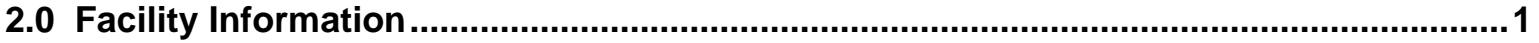

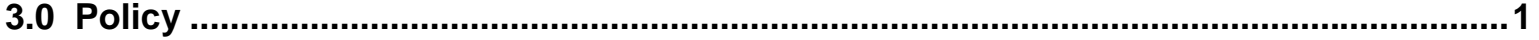

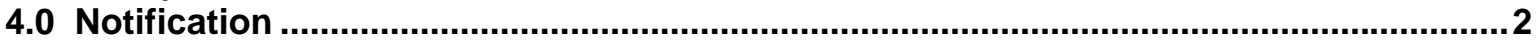

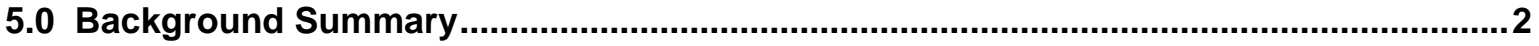

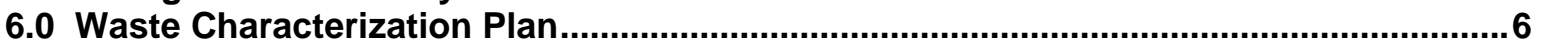

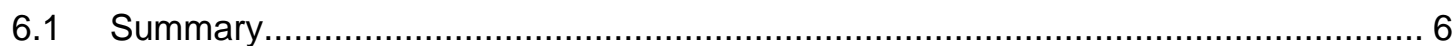

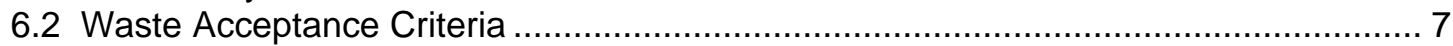

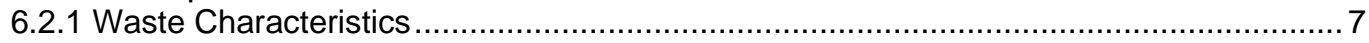

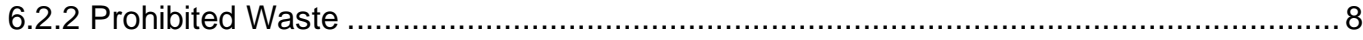

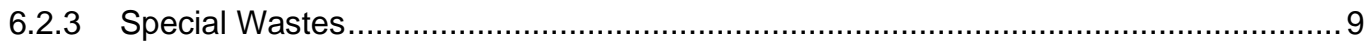

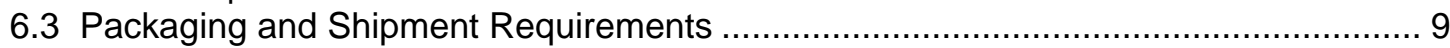

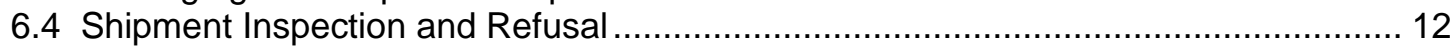

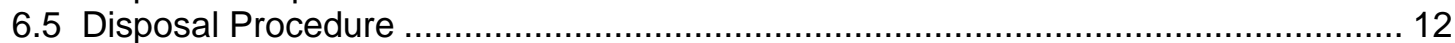

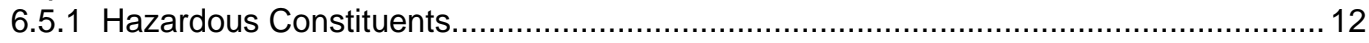

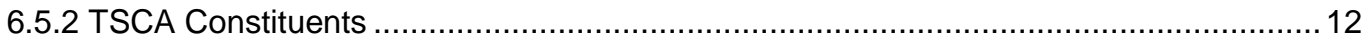

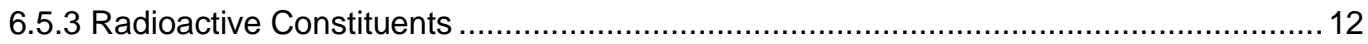

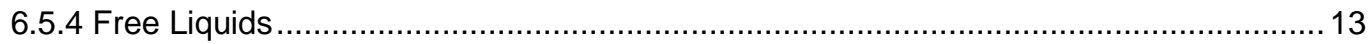

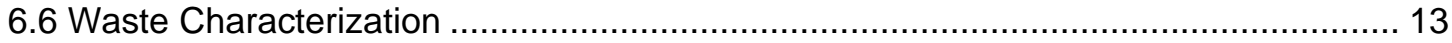

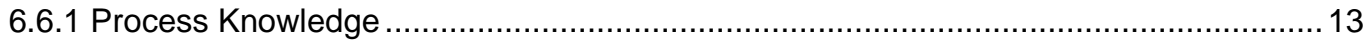

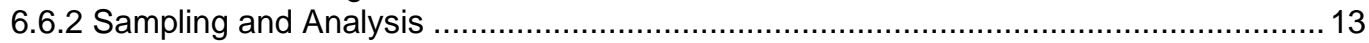

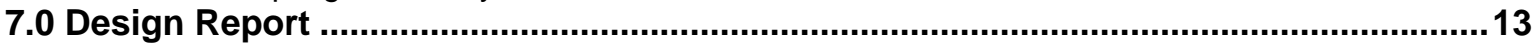

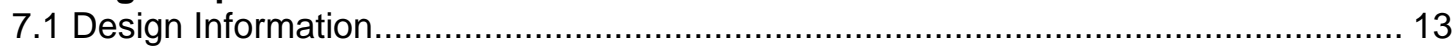

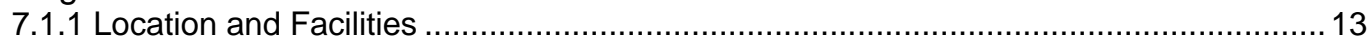

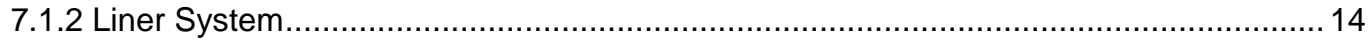

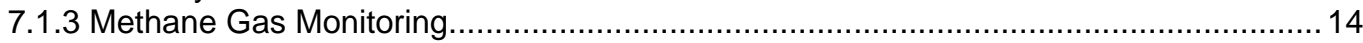

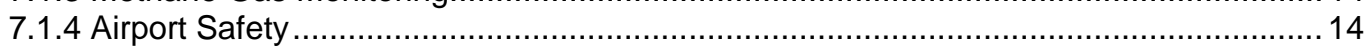

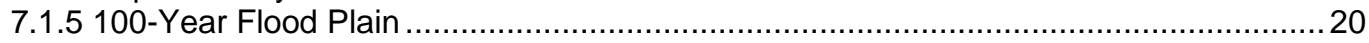

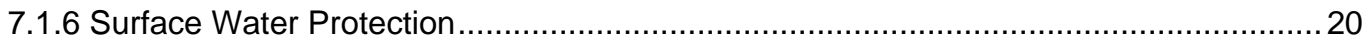

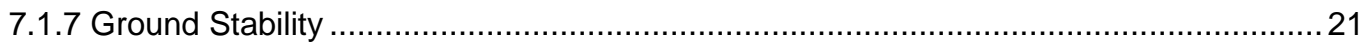

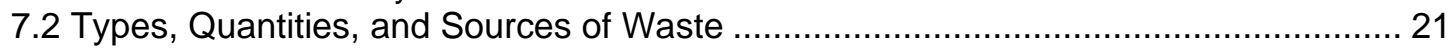

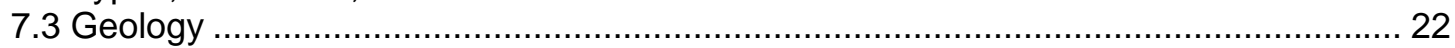

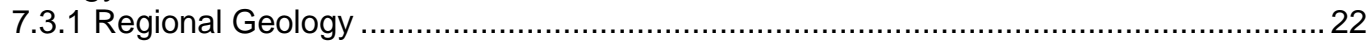

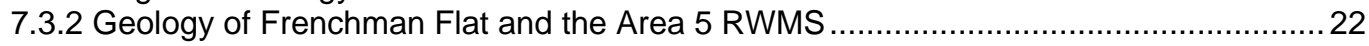

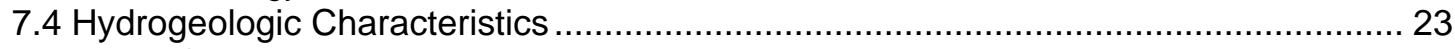

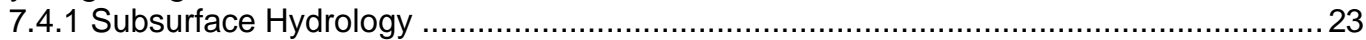

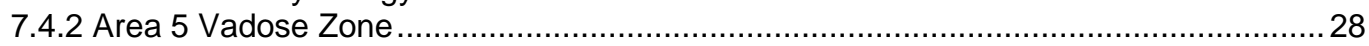

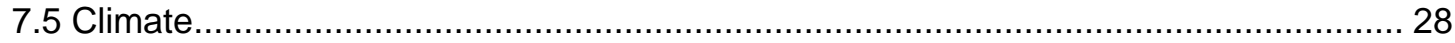

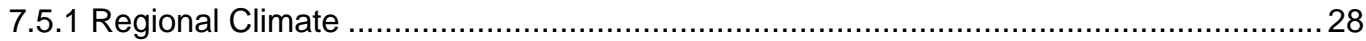

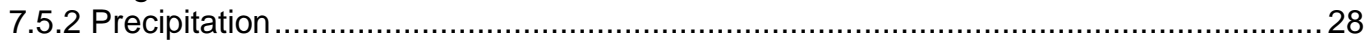

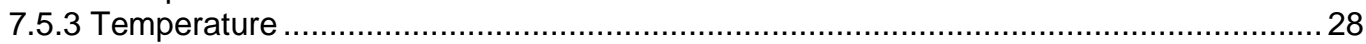

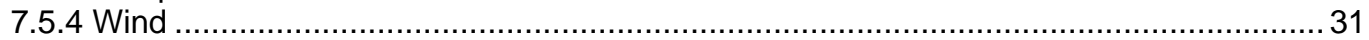

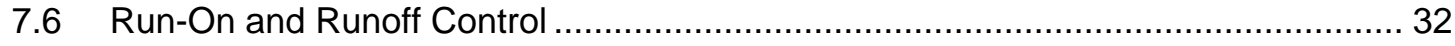

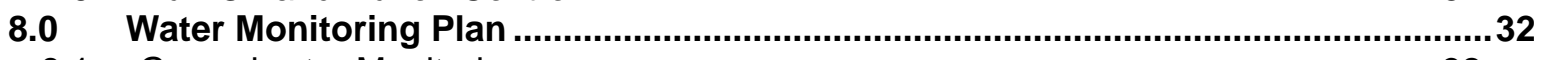

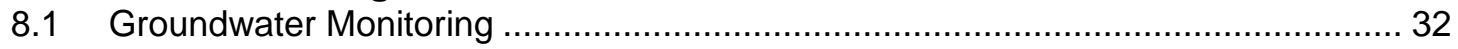

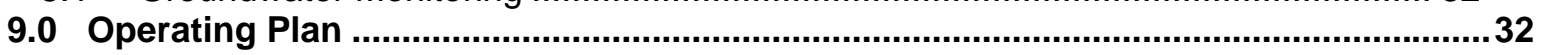

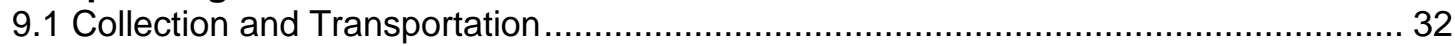

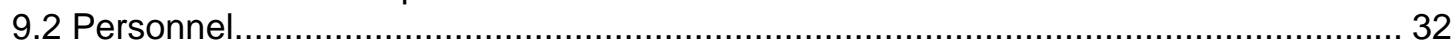

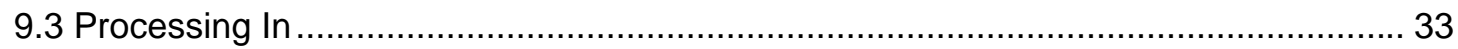

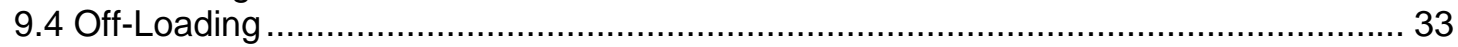

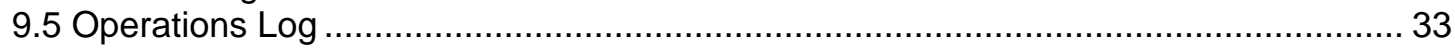

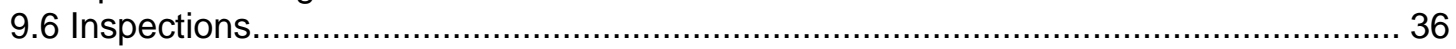

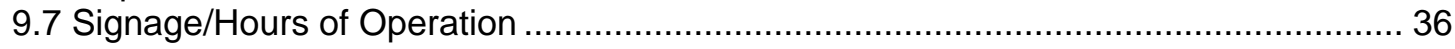




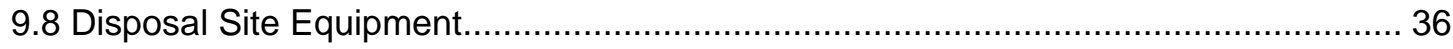

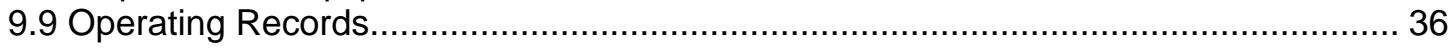

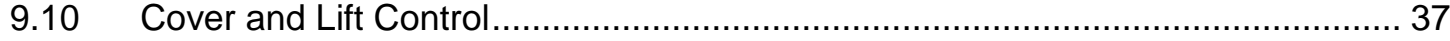

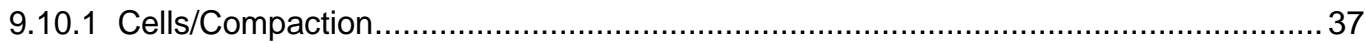

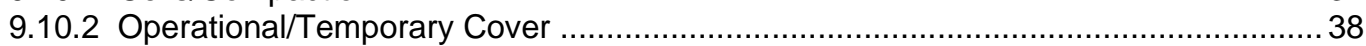

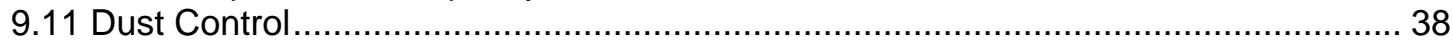

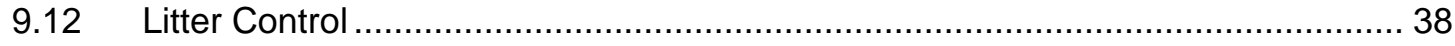

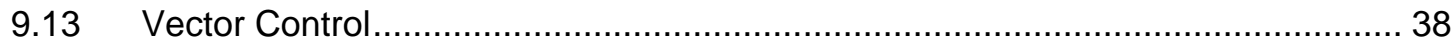

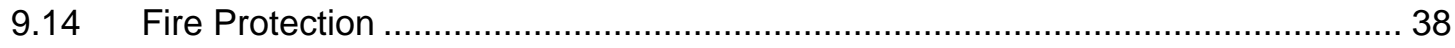

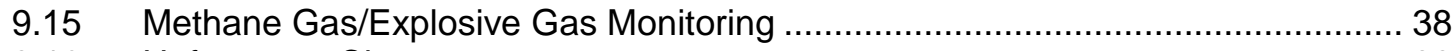

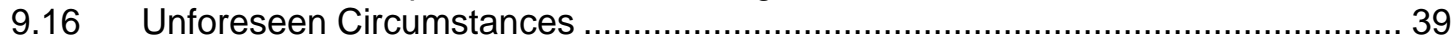

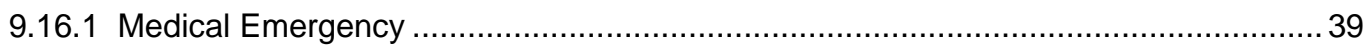

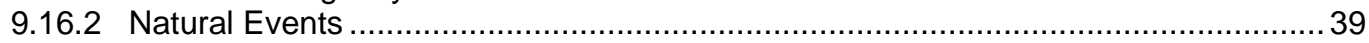

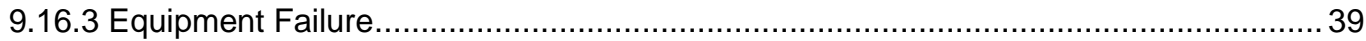

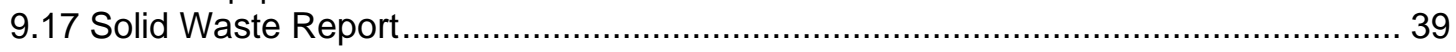

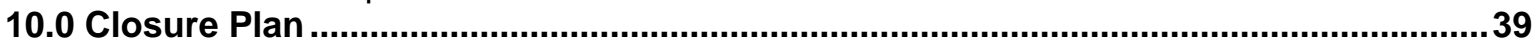

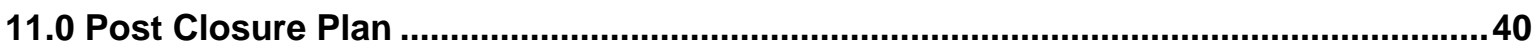

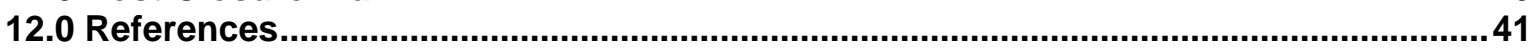




\section{List of Figures}

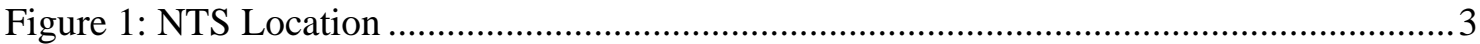

Figure 2: Location Map of the Area 5 Solid Waste Disposal Site........................................... 4

Figure 3: Asbestiform Low-Level Waste Disposal Site ........................................................ 5

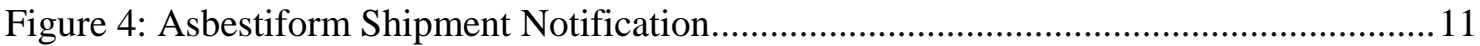

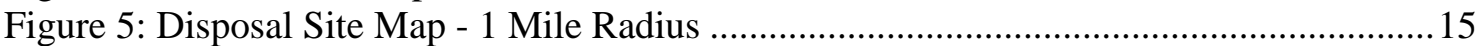

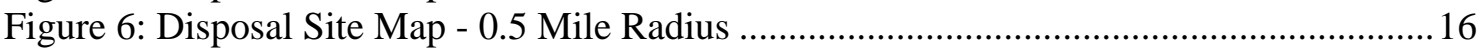

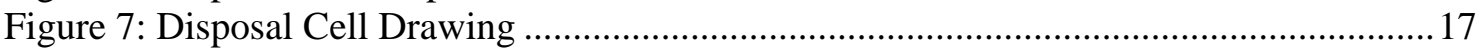

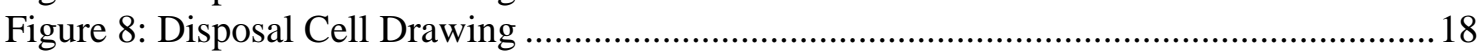

Figure 9: Flood Zones Associated with the Area 5 RWMS ................................................ 19

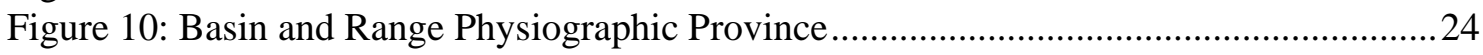

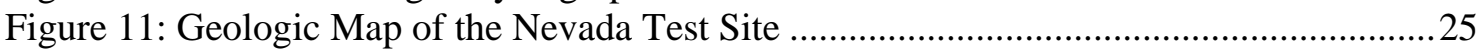

Figure 12: Major Landforms of Northern Frenchman Flats, NTS.........................................26

Figure 13: Groundwater Hydrologic Units of the NTS and Vicinity ...................................29

Figure 14: Map Showing the Pilot Wells in Relations to the Area 5 RWMS ......................... 30

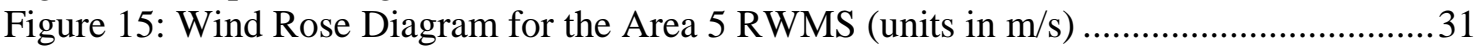

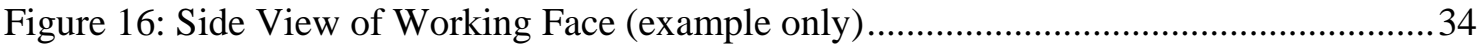

Figure 17: Profile of a Typical Disposal Unit at the Area 5 RWMS ......................................35 


\section{Acronyms and Abbreviations}

\begin{tabular}{|c|c|}
\hline $\mathrm{ACM}$ & Asbestos-Containing Material \\
\hline ALLW & Asbestiform Low-Level Waste \\
\hline BN & Bechtel Nevada \\
\hline CAAB & Controlled Area Access Building \\
\hline CCRFCD & Clark County Regional Flood Control District \\
\hline CFR & Code of Federal Regulations \\
\hline DOE & U.S. Department of Energy \\
\hline DOT & U.S. Department of Transportation \\
\hline EPA & U.S. Environmental Protection Agency \\
\hline FEMA & Federal Emergency Management Agency \\
\hline $\mathrm{ft}$ & foot/feet \\
\hline $\mathrm{ft}^{3}$ & cubic feet \\
\hline $\mathrm{km}$ & kilometer \\
\hline $\mathrm{km}^{2}$ & square kilometer(s) \\
\hline LLHB & Low-Level Radioactive Hydrocarbon-Burdened \\
\hline LLW & low-level waste \\
\hline mi & mile(s) \\
\hline Ma & million year \\
\hline $\mathrm{mi}^{2}$ & square miles \\
\hline mils & thousands of an inch \\
\hline $\mathrm{mg} / \mathrm{kg}$ & milligrams/kilogram \\
\hline NAC & Nevada Administrative Code \\
\hline $\mathrm{nCi} / \mathrm{g}$ & nanocuries/gram \\
\hline NDEP/BFF & $\begin{array}{l}\text { Nevada Division of Environmental Protection, Bureau of } \\
\text { Federal Facilities }\end{array}$ \\
\hline NNSA/NSO & $\begin{array}{l}\text { U.S. Department of Energy National Nuclear Security } \\
\text { Administration Nevada Site Office }\end{array}$ \\
\hline NSTec & National Security Technologies, LLC \\
\hline NTS & Nevada Test Site \\
\hline NTSWAC & Nevada Test Site Waste Acceptance Criteria \\
\hline $\mathrm{PCB}(\mathrm{s})$ & Polychlorinated Biphenyl \\
\hline PK & Process Knowledge \\
\hline ppm & parts per million \\
\hline RACM & Regulated Asbestos-Containing Material \\
\hline RCRA & Resource Conservation and Recovery Act \\
\hline REECO & Reynolds Electrical and Engineering Co., Inc \\
\hline RWAP & Radioactive Waste Acceptance Program \\
\hline RWMS & Radioactive Waste Management Site \\
\hline RWO & Radioactive Waste Operations \\
\hline SAP & Sampling and Analysis Plan \\
\hline SWDS & Solid Waste Disposal Site \\
\hline SWMA & Solid Waste Management Authority \\
\hline TPH & Total Petroleum Hydrocarbons \\
\hline TRU & Transuranic \\
\hline TSCA & Toxic Substance Control Act \\
\hline WAC & Waste Acceptance Criteria \\
\hline WEF & Waste Examination Facility \\
\hline WMP & Waste Management Program \\
\hline
\end{tabular}



$\mathrm{yd}^{3}$
${ }^{\circ} \mathrm{F}$
cubic yards
degrees Fahrenheit
${ }^{\circ} \mathrm{C}$ degrees Celcius 


\subsection{Applicant Information}

Land Manager:

(Owner)

\author{
U.S. Department of Energy \\ National Nuclear Security Administration \\ Nevada Site Office \\ Post Office Box 98518
}

Las Vegas, Nevada 89193-8518

Authorized Agent: Stephen M. Younger

President

\subsection{Facility Information}

Name:

County:

Location:
Area 5 Asbestiform Low-Level Waste Disposal Site

Nye County

Nevada Test Site (NTS), Area 5 Radioactive Waste Management Site (RWMS)

Nevada Coordinates: N 766,528 to N 767,200 by E 708,734 to E 708,893

(Based on Nevada State Plane Grid - Central Zone, North

American Datum, 1983)

\subsection{Policy}

The NTS solid waste disposal sites must be permitted by the state of Nevada Solid Waste Management Authority (SWMA). The SWMA for the NTS is the Nevada Division of Environmental Protection, Bureau of Federal Facilities (NDEP/BFF). The U.S. Department of Energy's National Nuclear Security Administration Nevada Site Office (NNSA/NSO) as land manager (owner), and National Security Technologies (NSTec), as operator, will store, collect, process, and dispose all solid waste by means that do not create a health hazard, a public nuisance, or cause impairment of the environment. NTS disposal sites will not be included in the Nye County Solid Waste Management Plan. 


\subsection{Notification}

Nevada Administrative Code (NAC) 444.685, "Financial Assurance” as referenced by NAC 444.733(9), “Application for Permit to Operate Class III Site or Lateral Expansion Thereof,” exempts entities of the federal government from the financial assurance requirements outlined in the state of Nevada solid waste disposal regulations. Therefore, these requirements are not addressed in this document. This document will function as part of the operating record for the disposal site described herein.

\subsection{Background Summary}

The NTS is located approximately 105 kilometers (km) (65 miles [mi]) northwest of Las Vegas, Nevada (Figure 1). The U.S. Department of Energy (DOE) is the federal lands management authority for the NTS, and NSTec is the Management and Operations contractor. Access on and off the NTS is tightly controlled, restricted, and guarded on a 24-hour basis. The NTS has signs posted along its entire perimeter.

NSTec is the operator of all solid waste disposal sites on the NTS. The Area 5 RWMS is the location of the permitted facility for the Solid Waste Disposal Site (SWDS). The Area 5 RWMS is located near the eastern edge of the NTS (Figure 2), approximately $26 \mathrm{~km}$ (16 mi) north of Mercury, Nevada. The Area 5 RWMS is used for the disposal of low-level waste (LLW) and mixed low-level waste. Many areas surrounding the RWMS have been used in conducting nuclear tests.

A Notice of Intent to operate the disposal site as a Class III site was submitted to the state of Nevada on January 28, 1994, and was acknowledged as being received in a letter to the NNSA/NSO on August 30, 1994. Interim approval to operate a Class III SWDS for regulated asbestiform low-level waste (ALLW) was authorized on August 12, 1996 (in letter from Paul Liebendorfer to Runore Wycoff), with operations to be conducted in accordance with the "Management Plan for the Disposal of Low-Level Waste with Regulated Asbestos Waste." A requirement of the authorization was that on or before October 9, 1999, a permit was required to be issued. Because of NDEP and NNSA/NSO review cycles, the final permit was issued on April 5, 2000, for the operation of the Area 5 Low-Level Waste Disposal Site, utilizing Pit 7 (P07) as the designated disposal cell.

The original permit applied only to Pit 7, with a total design capacity of 5,831 cubic yards ( $\mathrm{yd}^{3}$ ) $\left(157,437\right.$ cubic feet $\left.\left[\mathrm{ft}^{3}\right]\right)$. NNSA/NSO is expanding the SWDS to include the adjacent Upper Cell of Pit 6 (P06), with an additional capacity of 28,037 $\mathrm{yd}^{3}\left(756,999 \mathrm{ft}^{3}\right)$ (Figure 3). The proposed total capacity of ALLW in Pit 7 and P06 will be approximately 33,870 $\mathrm{yd}^{3}(0.9$ million $\left.\mathrm{ft}^{3}\right)$. 


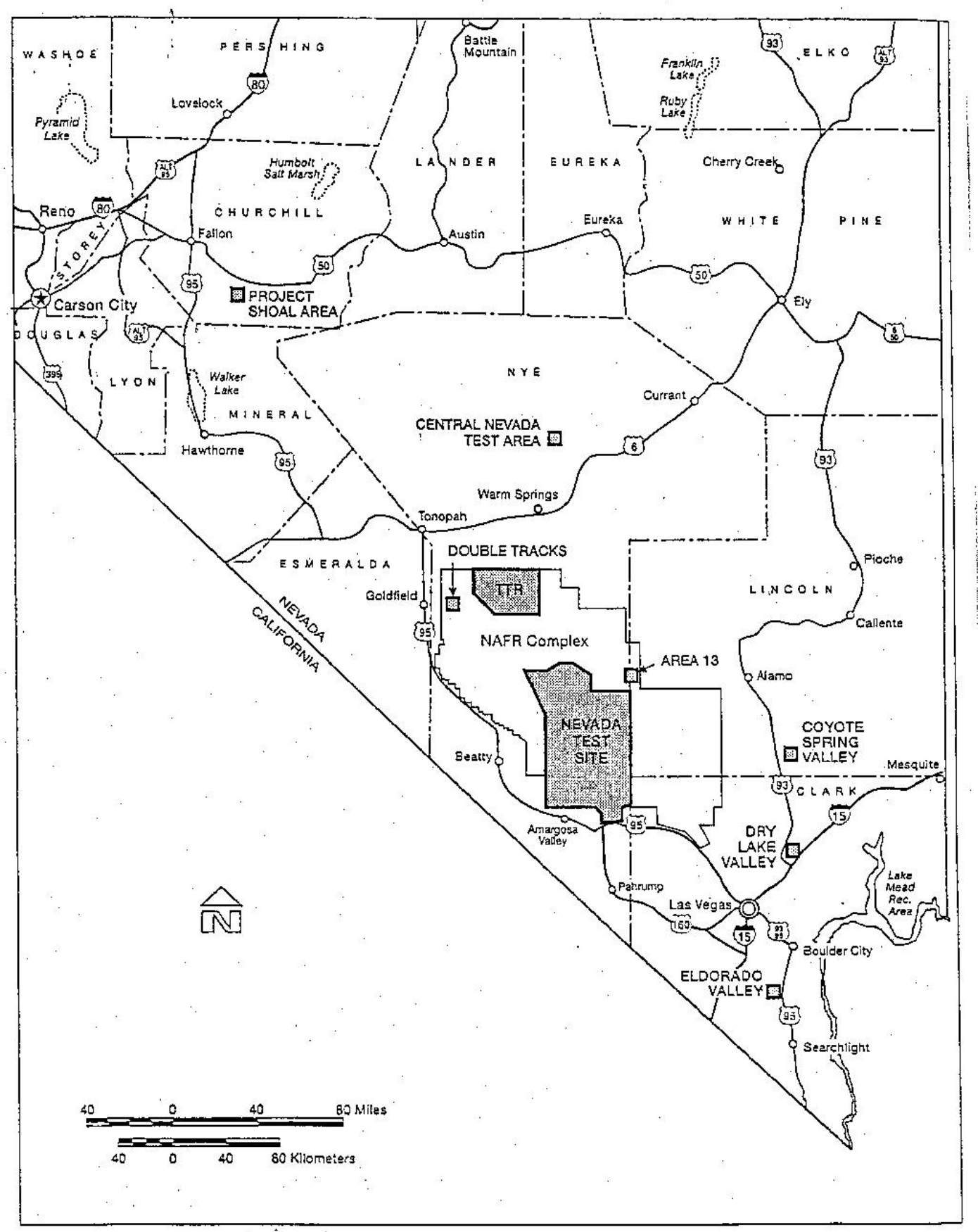

Figure 1: NTS Location 


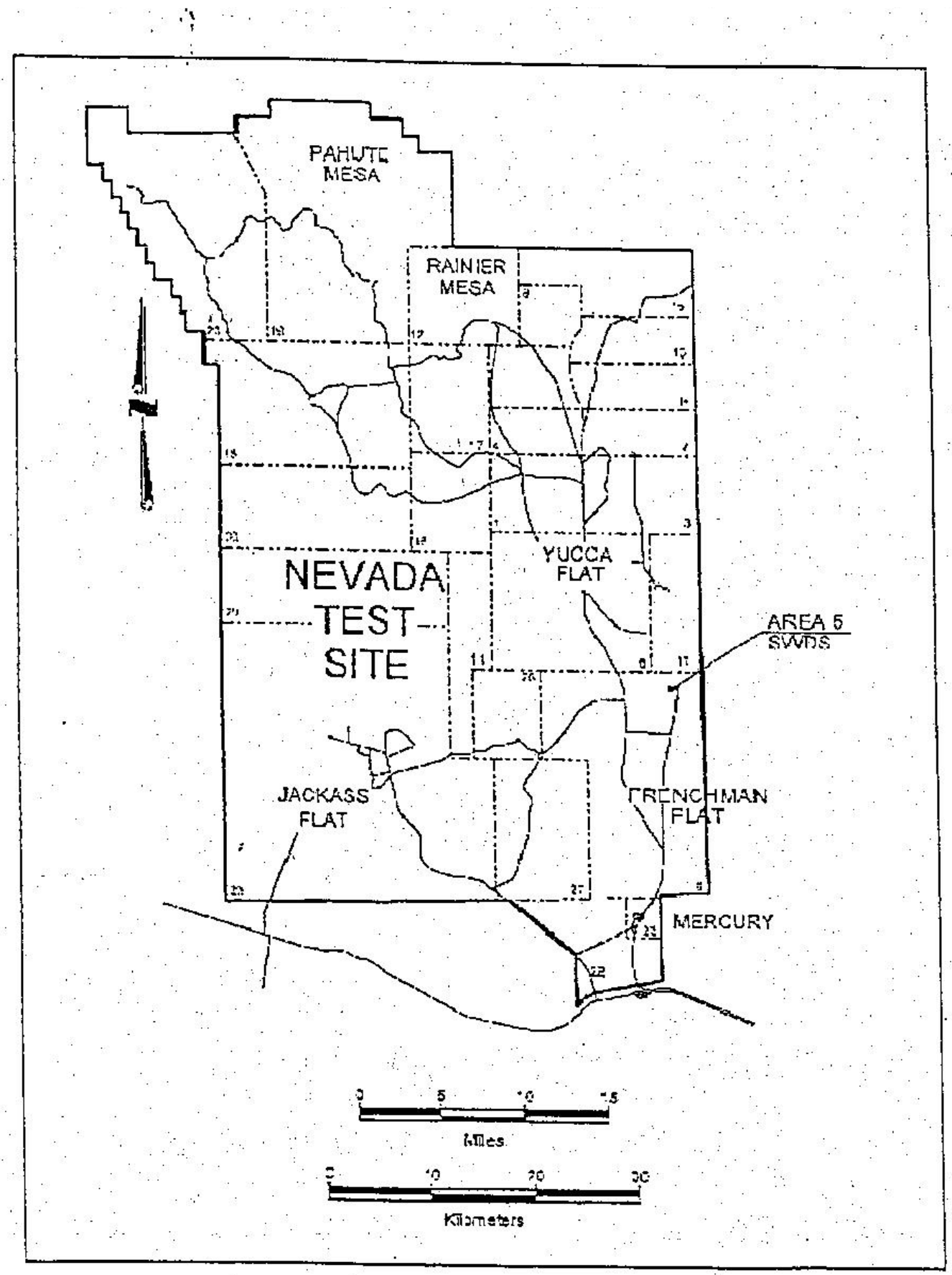

Figure 2: Location Map of the Area 5 Solid Waste Disposal Site 


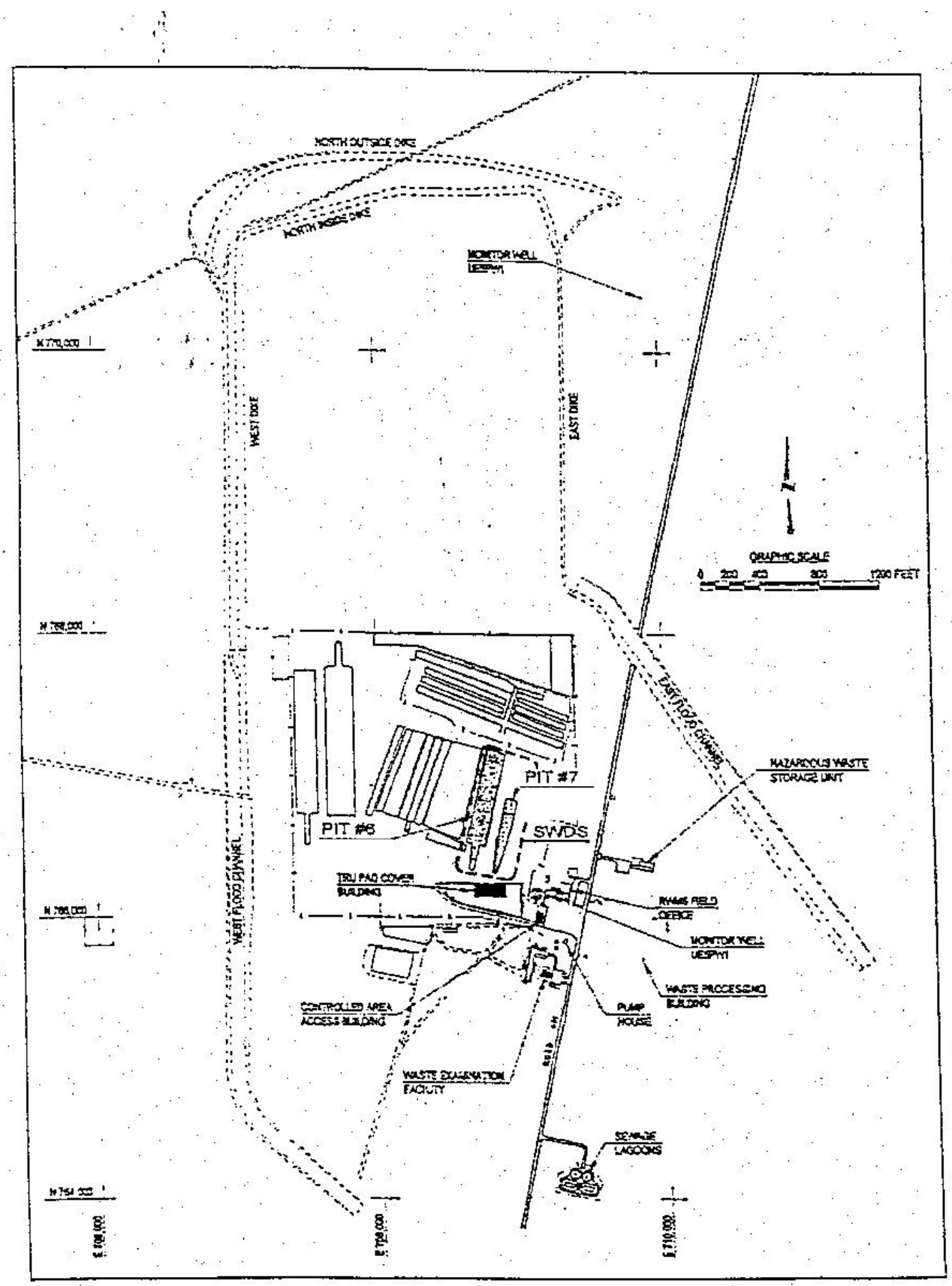

Figure 3: Asbestiform Low-Level Waste Disposal Site 


\subsection{Waste Characterization Plan}

\subsection{Summary}

The site will be used for the disposal of regulated ALLW, small quantities of low-level radioactive hydrocarbon-burdened (LLHB) media and debris, LLW, LLW that contains PCB Bulk Product Waste greater than $50 \mathrm{ppm}$ that leaches at a rate of less than 10 micrograms of PCB per liter of water, and small quantities of LLHB demolition and construction waste (hereafter called permissible waste). Waste containing free liquids, or waste that is regulated as hazardous waste under the Resource Conservation and Recovery Act (RCRA) or state-of-generation hazardous waste regulations, will not be accepted for disposal at the site. The only waste regulated under the Toxic Substances Control Act (TSCA) that will be accepted at the disposal site is regulated asbestos-containing materials (RACM). The term asbestiform is used throughout this document to describe this waste. Other TSCA waste (i.e., polychlorinated biphenyls [PCBs]) will not be accepted for disposal at the SWDS.

The disposal site will be used as a depository of permissible waste generated both on site and off site. All generators designated by NNSA/NSO will be eligible to dispose regulated ALLW at the Asbestiform Low-Level Waste Disposal Site in accordance with the U.S. Department of Energy, Nevada Operations Office (DOE/NV) 325, Nevada Test Site Waste Acceptance Criteria (NTSWAC, current revision). Approval will be given by NNSA/NSO to generators that have successfully demonstrated through process knowledge (PK) and/or sampling and analysis that the waste is low-level, contains asbestiform material, and does not contain prohibited waste materials. Each waste stream will be approved through the Radioactive Waste Acceptance Program (RWAP), which ensures that the waste meets acceptance requirements outlined in the NTS Class III Permit and the NTSWAC.

The SWDS will accept:

- Regulated ALLW that is generated by asbestos abatement programs administered by state or federal agencies pursuant to the TSCA.

- Regulated asbestiform low-level legacy waste.

- NNSA/NSO-generated LLHB media and debris and LLHB demolition and construction waste. This material may or may not be contaminated with regulated asbestiform material.

- $\quad$ LLW that meets the waste acceptance criteria in Section 6.2.

- LLW that meets the waste acceptance criteria in Section 6.2 and contains PCB Bulk Product Waste greater than $50 \mathrm{ppm}$ that leaches at a rate of less than 10 micrograms of PCB per liter of water.

- $\quad$ Other waste on a case-by-case basis, with concurrence from NDEP/BFF.

Regulated ALLW will be generated from DOE operations that encompass Defense Programs, Waste Management, Environmental Restoration, or Technology Development programs. Other 
sources generating regulated ALLW may be appraised on a case-by-case basis, with concurrence obtained from the NDEP/BFF before the waste may be accepted.

\subsection{Waste Acceptance Criteria}

The NTSWAC will be used as the governing document for waste acceptance criteria (also see NSTec Plan entitled "Management Plan for the Disposal of Low-Level Waste with Regulated Asbestos Waste", PLN-1013). Requirements stipulated in this document meet state of Nevada requirements to detect and prevent disposal of hazardous waste or PCB wastes, and restrictions on free liquids. The State of Nevada has granted NNSA/NSO an exclusion from the requirement for onsite random inspections for incoming loads (NAC 444.6665 [1] [a] \& [b], “Operating Criteria: Program for Detecting and Preventing Disposal of Regulated Hazardous Wastes and PCB Waste”). The RWAP conducts random inspections and verification of waste acceptance prior to shipment to the NTS. If and when a generator meets the RWAP approval requirements as described in the NTSWAC, the NNSA/NSO Assistant Manager for Environmental Management is responsible for providing proper written documentation to the generator allowing the waste to be sent to the site for final disposal.

Prior to accepting waste, disposal site operators will verify that the waste received at the site is from an approved generator. Generator compliance with the NTSWAC will ensure that the following are documented:

- $\quad$ The absence of prohibited materials

- The waste characterization information that identifies each load by type of permissible waste

- $\quad$ The process by which waste was characterized (PK, sampling and analysis, etc.)

- Identification of waste source by location (Area 2, Area 25 - Yucca Mountain Project Site Characterization Office, Sandia National Laboratories, Albuquerque, etc.)

Load verification information will be prepared by the waste generator and accepted at the disposal site prior to the waste being disposed. Inadequate documentation or waste characterization is cause to refuse entry and disposal of any load of solid waste.

\subsubsection{Waste Characteristics}

Permissible ALLW may include, but is not limited to, inert low-level materials known to contain or be contaminated with RACM. RACM includes:

- Friable asbestos material

- Category I nonfriable asbestos-containing material (ACM) that has become friable

- Category I nonfriable ACM that will be or has been subjected to sanding, grinding, cutting, or abrading

- Category II nonfriable ACM that has a high probability of becoming or has become crumbled, pulverized, or reduced to powder by the forces expected to act on the material in the course of demolition or renovation operations regulated by Title 40 Code of Federal Regulations (CFR) 61, Subpart M, "National Emission Standards for Asbestos.” 
Permissible regulated ALLW may include, but is not limited to, the following materials:

- Asphalt

- Ductwork

- Glove box frames

- Insulation

- Metal

- Wood

- Paper

- Floor tile
- Personal protective equipment

- Metal or plastic pipe

- Rocks

- Soil

- Transite

- Roofing materials

- Miscellaneous building materials

Permissible LLHB waste includes LLHB media and debris and LLHB demolition and construction waste. This material may or may not be contaminated with regulated asbestiform material, but must be low-level. To be considered hydrocarbon-burdened, the material must exceed 100 milligrams/kilogram (mg/kg) of Total Petroleum Hydrocarbons (TPH) using U.S. Environmental Protection Agency (EPA) Method 8015, modified. Permissible LLW must meet the waste acceptance criteria in Section 6.2. Permissible LLW may also contain PCB Bulk Product Waste greater than $50 \mathrm{ppm}$ that leaches at a rate of less than 10 micrograms of PCB per liter of water.

NNSA/NSO shall act as the solid waste management authority in meeting the applicable requirements of NAC 444.965-444.976, "Transportation and Disposal," (excluding NAC 444.974[2]), "Disposal of Asbestos."

\subsubsection{Prohibited Waste}

The following RACM are specifically prohibited from disposal:

- High-level radioactive waste

- Transuranic (TRU) waste (alpha-emitting TRU nuclides with half-lives greater than 20 years and a concentration greater than 100 nanoCuries/gram [nCi/g])

- Radioactive waste from DOE or commercial operations that produce nuclear power for public consumption

- Sewage pumpings and sludge

- Septic tank pumpings and sludge

- Hazardous waste

- Medical waste

- Waste containing free liquids

- Tires

- Other materials prohibited by law 


\subsubsection{Special Wastes}

NNSA/NSO-generated LLHB media and debris and LLHB demolition and construction waste may or may not be contaminated with regulated asbestiform material. To be considered hydrocarbon-burdened, the material must exceed $100 \mathrm{mg} / \mathrm{kg}$ of TPH using EPA Method 8015, modified. Any material not exceeding $100 \mathrm{mg} / \mathrm{kg}$ of TPH will not be considered hydrocarbon-burdened.

\subsection{Packaging and Shipment Requirements}

Prior to the packaging and shipping, the generator will ensure that RACM will be wetted with a water and surfactant mixture and packaged in one of the following:

- A plastic bag or equivalent that is not less than 6 mils (thousandths of an inch) thick and sealed so that it is airtight

- A combination of plastic bags that equal at least 6 mils in thickness

- A container that is lined with plastic.

If free liquid is present, absorbent will be added to ensure compliance with the free liquids criteria (as defined in Section 6.5.4). Sharp edges and corners in the package will be padded or protected to prevent damage to the plastic bag during handling, shipping, and disposal.

RACM (packaged as stated above) and LLHB waste will be packaged inside steel drums, lined wooden boxes, steel boxes, or Sealand ${ }^{\circledR}$ containers. Package specifications ensure that waste packages will not emit particulate matter and will not be crushed during stacking and covering operations. These specifications exceed the standards for asbestos packaging identified in NAC 444.971., "Standards for Handling and Transportation.” Each shipment of LLHB waste shall be accompanied by a bill of lading or shipping manifest.

Each container used to dispose RACM will bear a label that displays one of the following statements.

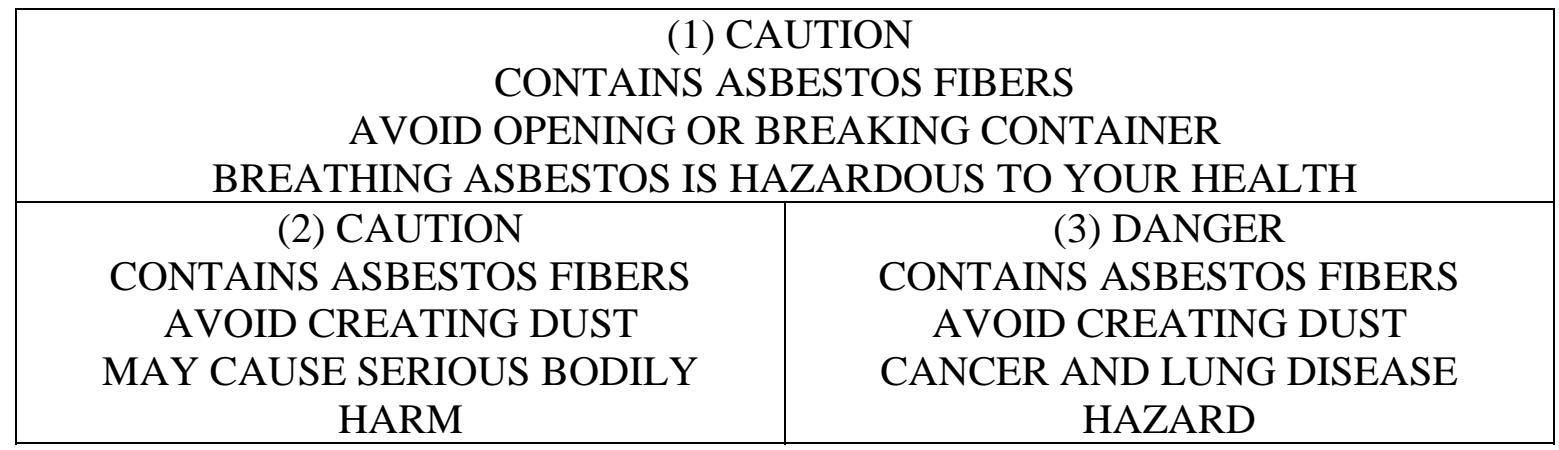

The transporter is responsible for transporting waste in a manner that will prevent the airborne release of waste material. It is the responsibility of the generator and transporter to comply with NAC 444.972(1), “Approval Required for Transportation,” and U.S. Department of Transportation (DOT) requirements for the shipment of waste material to the NTS. 
Generators will ensure that transporters of regulated ALLW, LLW, LLW containing PCBs, and LLHB waste meet the requirements of DOE Order 460.2, "Departmental Materials

Transportation and Packaging Management," which specifies that transporters of hazardous materials must pass the DOE Motor Carrier Evaluation Program.

Each generator shipping-regulated ALLW to the NTS shall complete the Asbestiform Shipment Notification (Figure 4), or equivalent, for each shipment number and forward it to NNSA/NSO, no later than seven days in advance of the shipment's arrival at NTS. The Asbestiform Shipment Notification is for RACM only. LLW, LLW containing PCBs, and LLHB waste will follow the standard requirements for LLW as described in the NTSWAC. NNSA/NSO will sign the notification and forward a copy to the NDEP/BFF Las Vegas office and to both the NSTec Waste Management Program offices in Las Vegas and at the Area 5 RWMS no later than four days in advance of arrival at the NTS. A signed copy of the notification will be returned immediately to the generator indicating authorization of shipment. This process will fulfill the requirements of NAC 444.972.2, "Submission of Information to Obtain Approval”; and NAC 444.974, "Notification Required Before Delivery; Disposal at Site Other Than Class I Disposal Site."”

NSTec shall act as the solid waste management authority in satisfying the requirements of NAC 444.973," Maintenance and Filing of Records Regarding Transportation.” Each waste shipment of regulated ALLW shall be accompanied by a bill of lading or shipping manifest and a copy of the Asbestiform Shipment Notification signed by NNSA/NSO Waste Management Project. This documentation will be retained by NSTec (see Section 9.9). The transporter or generator will not be required to submit a copy of the Asbestiform Shipment Notification to the state of Nevada. 


\section{ÀSBESTIFORM SHIPMENT NOTIFICATION \\ Fax to (702) 295-1153}

The generator signed below shall submit this notification to NNSANSO at least seven days in advance of arrival of shipment of Asbestiform low-level waste to the Area 5 Radioactive Waste Management Site (RWMS).

Generator:

Generator Address:

Generator Telephone Number: Fax Number:

Transporter Name:

Transporter Address:

Transporter Telephone Number: Fax Number:

Waste Stream Identification Number:

Shipment Number:

Number of Containers: Net Weight of Waste: Net Volume of Waste:

Shipment Date: (Approximate)

Arrival Date: *Arrival Date is dependent on weather and other conditions.

I certify that the wastes in this shipment are packaged and labeled to the asbestos requirements and are Asbestiform low-level radioactive waste authorized for disposal by NNSAINSO.

Generator Signature

Note: Failure to notify NNSAINSO seven days in advance of shipment may result in refusal of shipment.

\section{FOR NNSA/NSO USE ONLY}

The above NNSAINSOMMP signature authorizes the generator to release the identified shipment. If you have any questions or comments, please call NNSANSOMMP at (702) 295-7063.

To: (Generator)

From: NNSANSOMMP

CC: NDEP BFF (Las Vegas) - (702) 468-2863

This is an oficial notice for the identified Asbestiform shipment.

NSTec WMP (Area 5) - (702) 295-6852

This is an official authorization to receive the identified Asbestiform shipment.

\section{Figure 4: Asbestiform Shipment Notification}




\subsection{Shipment Inspection and Refusal}

NSTec Radioactive Waste Program (RWP)/Radioactive Waste Operations (RWO) personnel shall inspect each load at the Area 5 RWMS to verify external packaging compliance and shipping documentation. The following examples are cause for refusing delivery of the regulated ALLW, LLW, LLW containing PCBs and LLHB waste for disposal at the Area 5 RWMS:

- Required paperwork not available or incomplete

- Labels do not meet the feral or state requirements

- Records or observations indicate that unauthorized/prohibited materials are in the shipment

These discrepancies will result in all, or portions, of the shipment being set aside in the staging area until the identified issue is resolved with the waste generator, and corrective action is taken. If mitigation action is neither satisfactory nor timely (e.g., within 45 days after receipt), wastes may be returned to the generator. This decision will be made by the appropriate NNSA/NSO and contractor Project Managers, and will take into consideration such items as DOT compliance, hazards involved with mitigation, and the safety of personnel. If the waste is not returned to the generator, corrective action will take place at the NTS, and the generator will be billed accordingly.

\subsection{Disposal Procedure}

The SWDS, a separate area within the Area 5 RWMS, has been designated for the disposal of regulated ALLW and NNSA/NSO-generated LLHB waste. The following practices will be used when handling and disposing of regulated ALLW or LLHB waste and LLW or LLW containing PCBs in Pit 6:

- Each package or container will be handled in a manner that minimizes breakage or breaching

- Vehicles that contained a package or container that leaked will be decontaminated if determined by RWO personnel to be necessary.

\subsubsection{Hazardous Constituents}

Waste will not be accepted for disposal if it is determined that the material contains a RCRAlisted constituent, displays a RCRA characteristic, or if it qualifies as being hazardous under state-of-generation or state of Nevada hazardous waste regulations.

\subsubsection{TSCA Constituents}

Permissible LLW may also contain PCB Bulk Product Waste greater than 50 ppm that leaches at a rate of less than 10 micrograms per liter of water.

\subsubsection{Radioactive Constituents}

No high-level waste, TRU waste (alpha-emitting TRU nuclides with half-lives greater than 20 years and a concentration greater than $100 \mathrm{nCi} / \mathrm{g}$ ), or waste from $\mathrm{DOE}$ or commercial operations that produce nuclear power for public consumption will be accepted. 


\subsubsection{Free Liquids}

Waste that contains free liquids greater than 1 percent of the volume of the waste when the waste is in a disposal container, or 0.5 percent of the volume of the waste processed to a solidified form will not be accepted at the disposal site. Sufficient sorbing material will be mixed with the waste to ensure that free liquids do not exist before being accepted at the disposal site.

\subsection{Waste Characterization}

Waste characterization is the process of identifying the chemical and physical properties of the waste material. It will be used to determine that permissible waste meets waste acceptance criteria and to ensure that it will not create an environmental hazard or threaten the health of the general public. Waste characterization will be achieved through PK, sampling and analysis, or a combination of these methods.

\subsubsection{Process Knowledge}

Generators may be able to adequately characterize waste by their familiarity and experience with the process by which the waste was generated. PK relies on a waste generator's knowledge of the chemical properties of process ingredients, including concentration levels of contaminants in the ingredients at the start of the process, and how each step of the process chemically and/or physically affected the processed material by adding, removing, producing, depleting, or neutralizing the contaminants in process ingredients, by-products, and/or finished products. Material Safety Data Sheets often are used as a means of identifying the process ingredients and, through the generator's knowledge of the process, the waste can be characterized.

PK may also be derived through the repeated analyses of the same event. From repeated sampling and analyses, waste may be characterized without further analysis.

\subsubsection{Sampling and Analysis}

If the generator cannot accurately characterize the waste using PK, it is the responsibility of generator personnel to prepare Sampling and Analysis Plans (SAPs) for all suspected permissible waste, including waste that appears to be extraordinary or unfamiliar. Using SAPs, generator personnel can properly characterize each waste for RCRA analytes, RCRA characteristics, PCBs, or radioactivity.

\subsection{Design Report}

\subsection{Design Information}

\subsubsection{Location and Facilities}

The Area 5 RWMS is sited in the southeast portion of the NTS and near the northern reaches of Frenchman Flat (Figure 2), approximately 26 km (16 mi) north of Mercury, Nevada. Although Pit 7 opened in September 1997, it has been utilized only for disposal of low-1eve1 radioactive RACM.

Figure 5 is a map indicating all features within an area having a radius of $1.6 \mathrm{~km}(1.0 \mathrm{mi})$ and centered on the disposal site. Figure 6 shows an area having a radius of $0.8 \mathrm{~km}(0.5 \mathrm{mi})$ surrounding the disposal site and identifies the location of fencing, site facilities, sewage lagoons, groundwater monitoring wells, drainage channels, and adjacent facilities. The closest 
inhabited structures include the Controlled Area Access Building (CAAB), the Area 5 RWMS Field Office, the Waste Examination Facility (WEF), and the mobile vendors supporting the WEF. Employees are assigned to these structures each working day. Disposal cell drawings are depicted in Figures 7 and 8.

Travel to the RWMS is by permanent, paved roads constructed on the NTS. The RWMS is enclosed by a perimeter fence, with access controlled by RWO personnel in the CAAB. This prevents unauthorized disposal of solid waste and prevents unauthorized personnel from entering the site. The entrance to the RWMS is posted with a sign that directs all personnel to go to the main office building before they are allowed into the RWMS disposal site. Past the CAAB is a roadway consisting of tightly compacted soil and gravel that branches off in several directions, eventually leading to the SWDS. There are signs at the entrance of the active cells which indicate that an asbestos dust hazard may be present.

Site facilities consist of a controlled access building, an office building, and various other buildings and sheds used to support the Area 5 RWMS activities. Electrical power, a radio communication system, telephones, toilets, showers, and potable water dispensers are available at the site.

\subsubsection{Liner System}

There is no liner system at the site. This Class III SWDS is allowed an exception from the strict liner requirements. The disposal site is located in an area that has a very high evapotranspiration rate, low annual precipitation, and a very deep water table. In addition, free liquids are prohibited. These disposal site characteristics, disposal requirements, and form criteria are not conducive to the generation of leachate, and no significant amounts of leachate are anticipated.

\subsubsection{Methane Gas Monitoring}

Based on past knowledge of the physical and chemical composition of the waste, and on the low annual rainfall, combined with high evapotranspiration at the disposal site, the generation and accumulation of explosive or toxic gases is considered minimal or nonexistent. Therefore, gas monitoring is not considered necessary during the active life of the Area 5 SWDS.

\subsubsection{Airport Safety}

No airports are located within $3 \mathrm{~km}$ (2 mi) of the disposal site, and the nearest ones are not available for public use; therefore, airport requirements applicable to state of Nevada solid waste disposal site requirements are not applicable to this disposal site. 


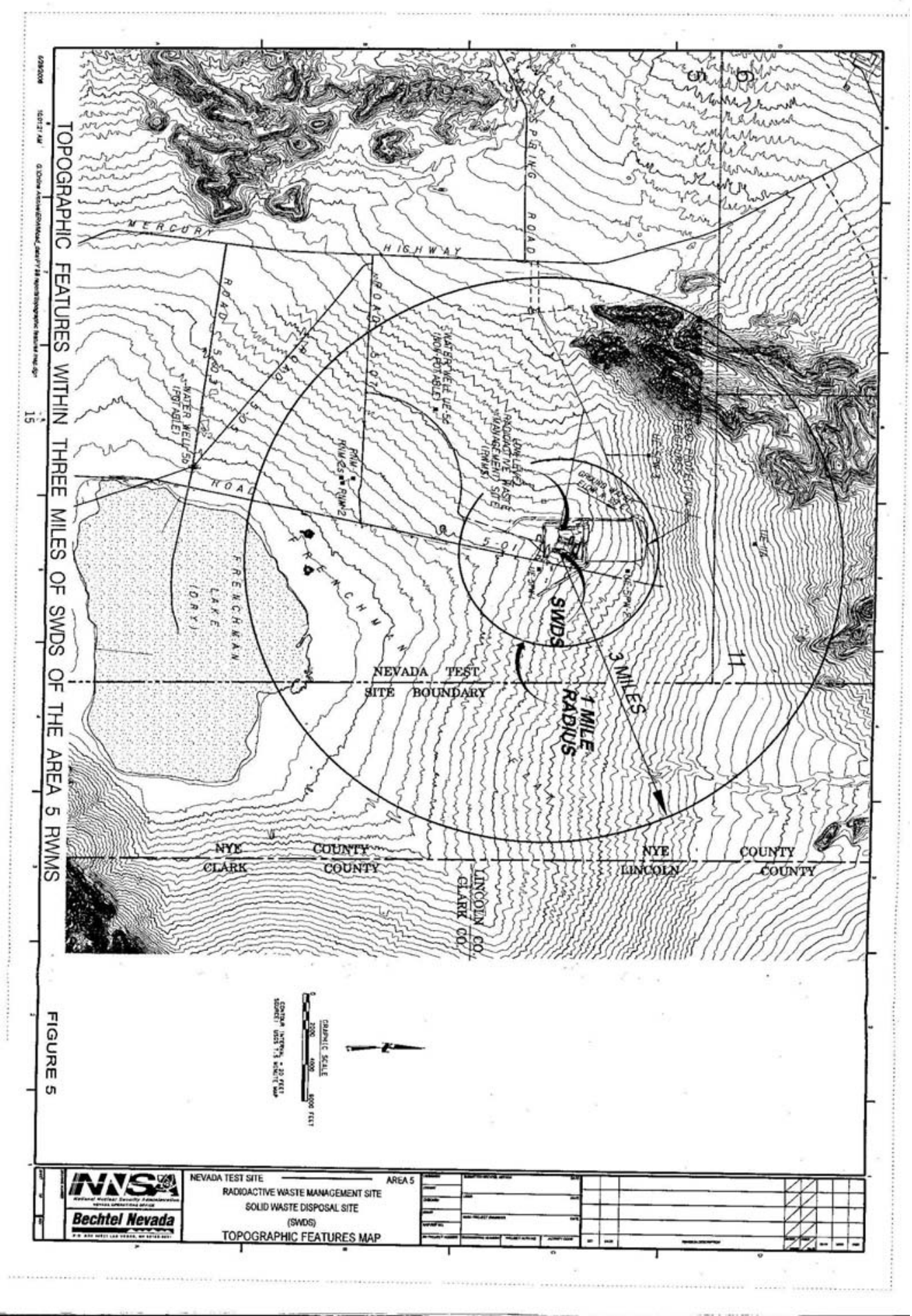

Figure 5: Disposal Site Map - 1 Mile Radius 


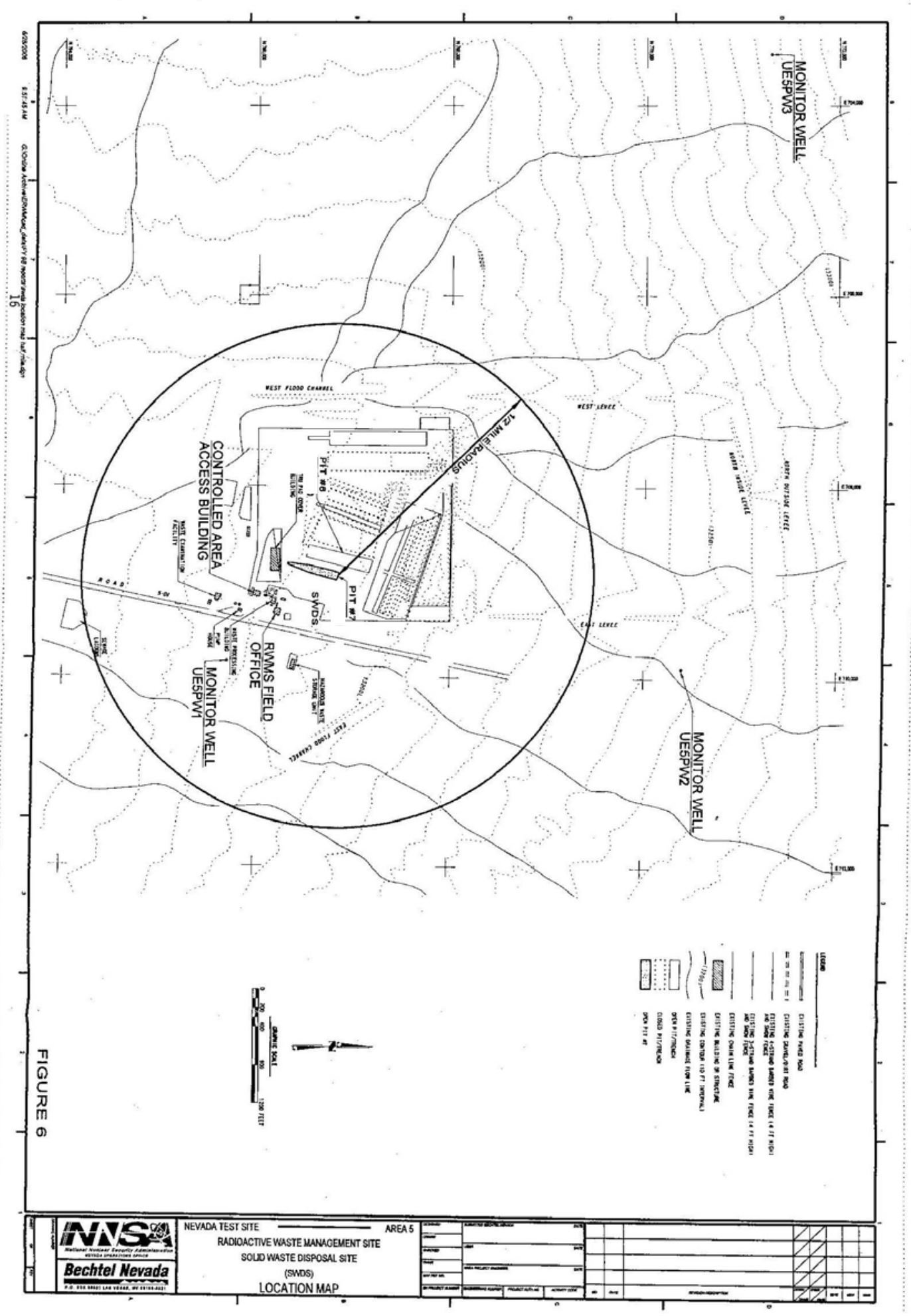

Figure 6: Disposal Site Map - 0.5 Mile Radius 


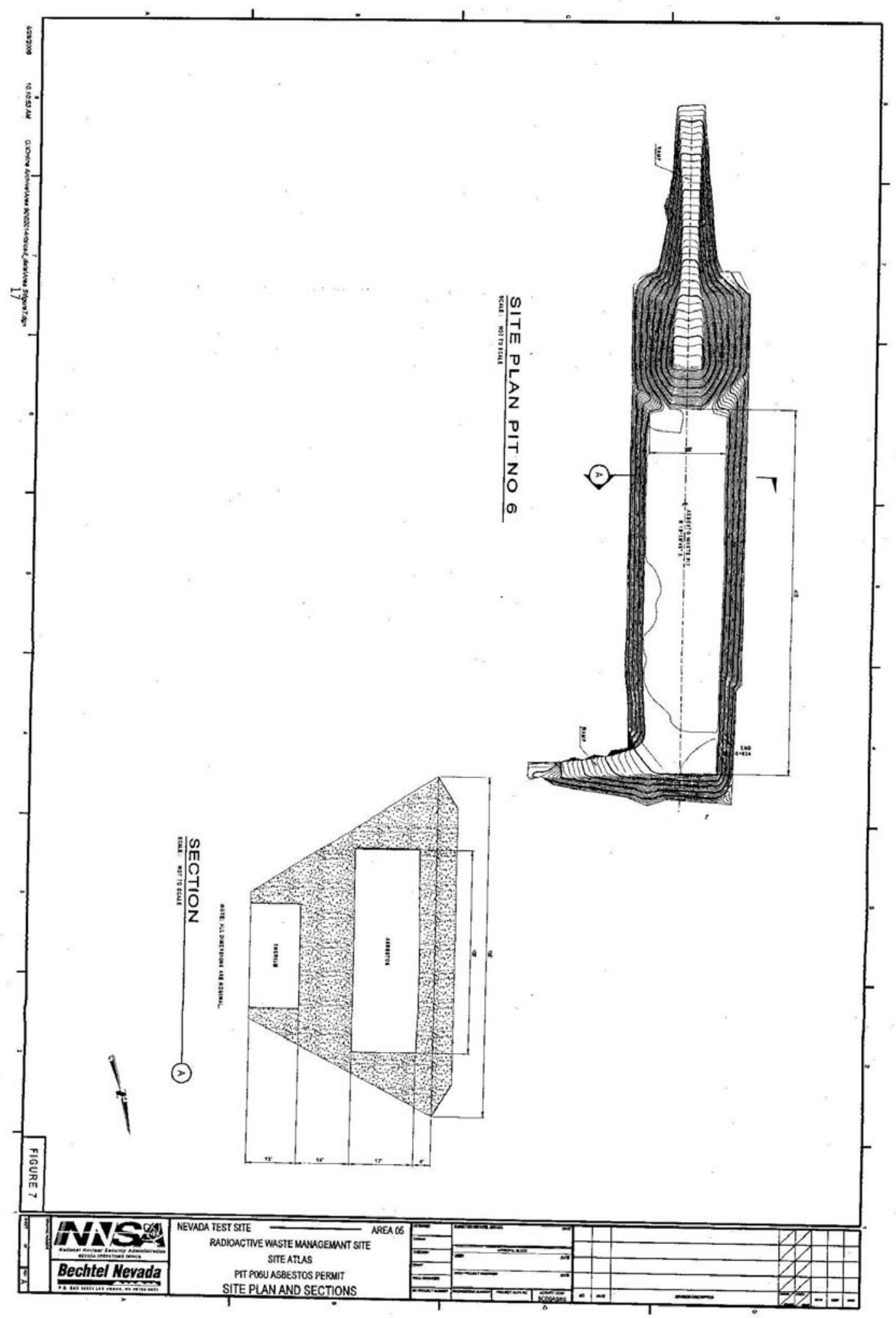

Figure 7: Disposal Cell Drawing 


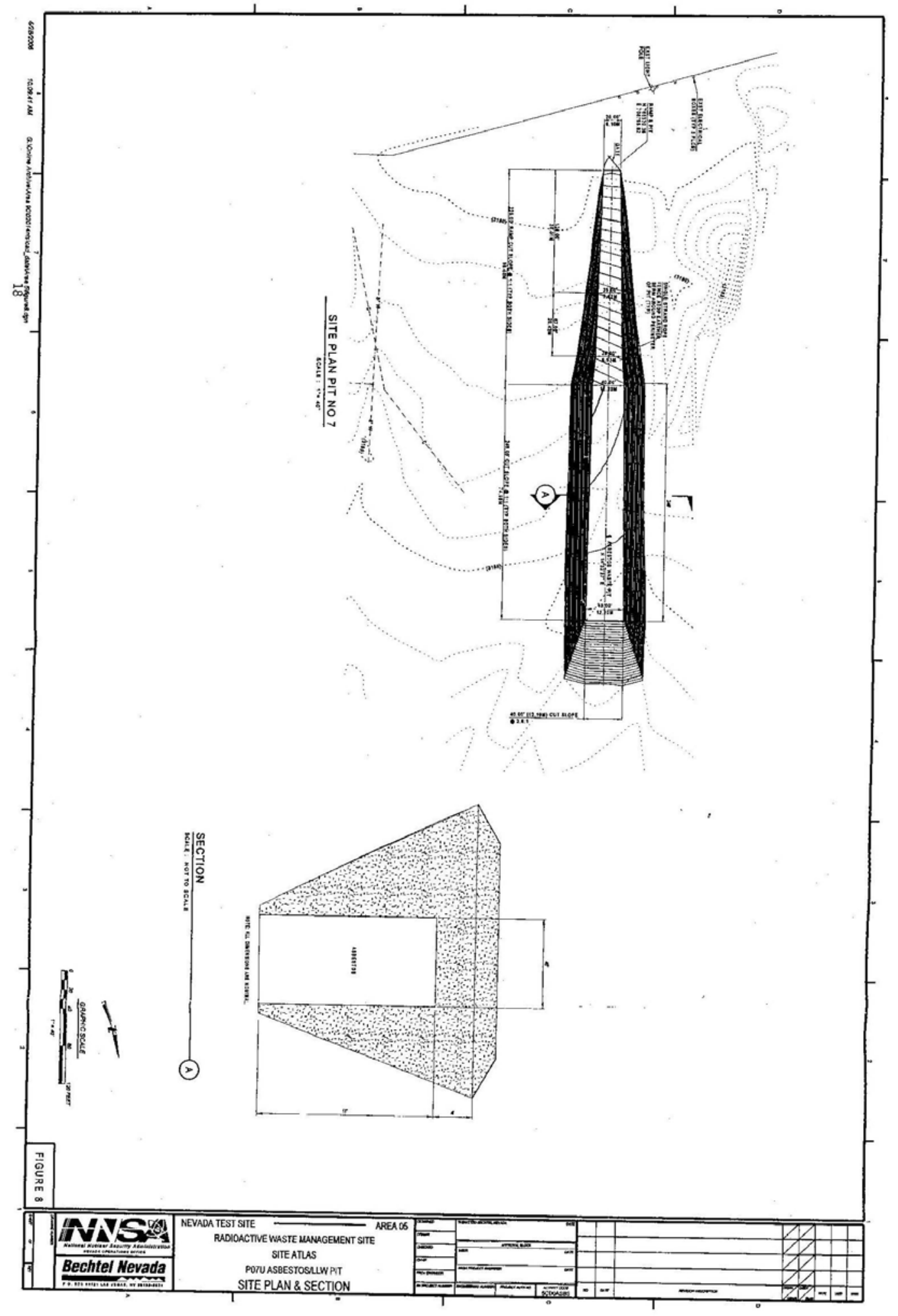

Figure 8: Disposal Cell Drawing 


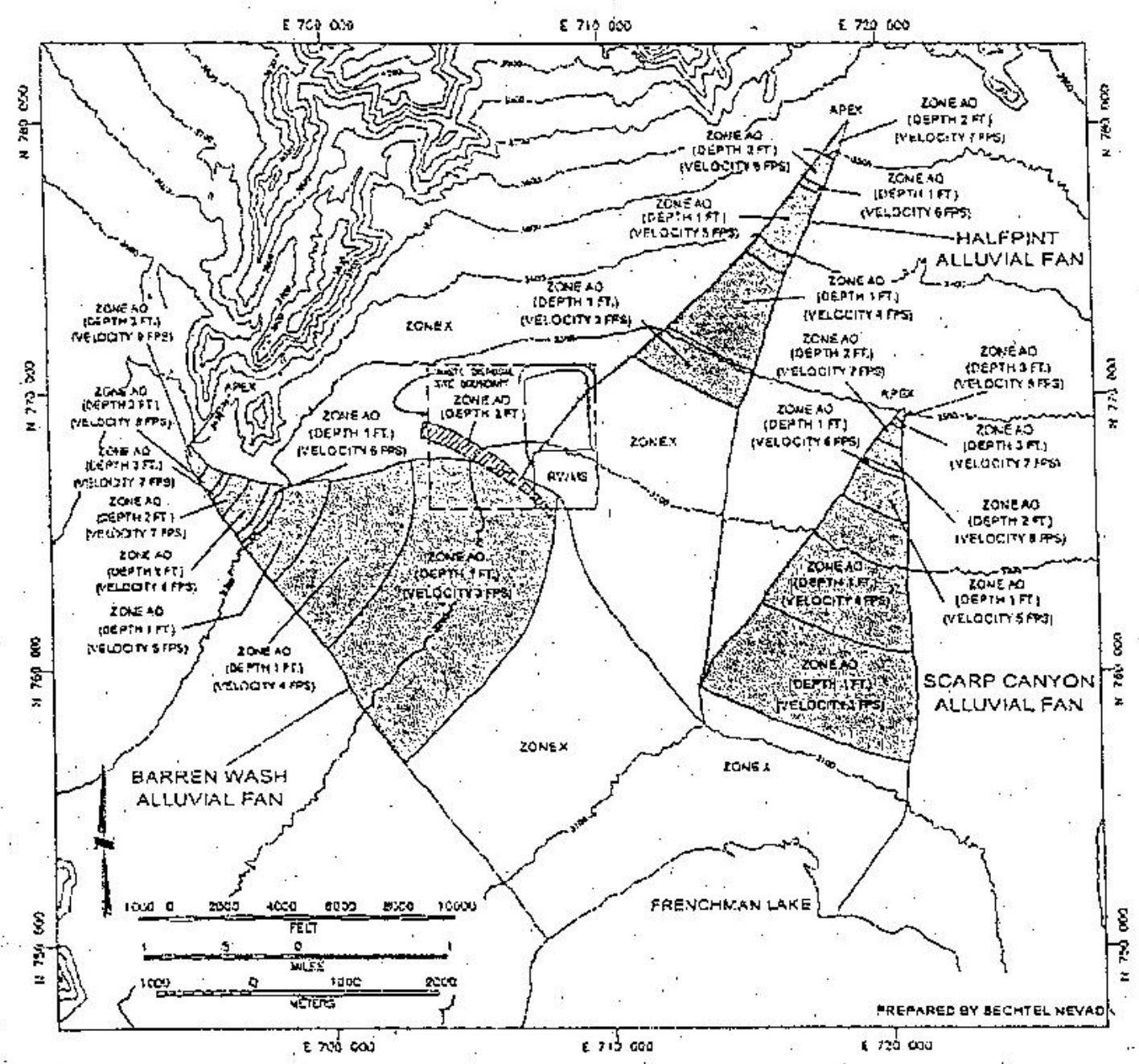

Extannamion

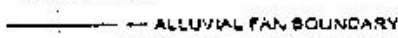

- DOUVHARV OF RMDIOACTNE WASTE VANAGELENT SITE GRMAS

- - - - BOUNOARY OF AREA PRORGSED FOK RW MS EXPANG:ONS

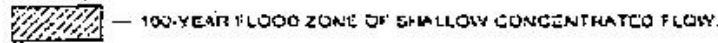

-AREN OF ALLLNMAL FAN IGOVEAR FLOCO ZONE

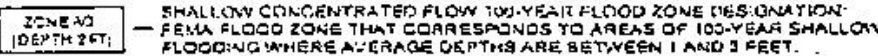

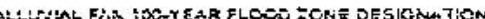

ZONEAO

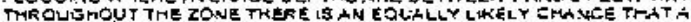
CHANKEL OAN DCEUR OF THE CES EWITEO CEPTH WITH A FLON OF THE OESUGATTEO VILLOCIT

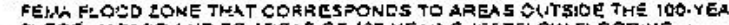

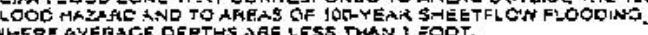

Figure 9: Flood Zones Associated with the Area 5 RWMS 


\subsubsection{0-Year Flood Plain}

Following Federal Emergency Management Agency (FEMA) guidelines, a flood assessment was performed at the Area 5 RWMS to determine the 100-year flood hazards at the facility (Miller et al., 1994 [Appendix A]). The flood hazard assessment was conducted according to guidelines of the Clark County Regional Flood Control District (CCRFCD) Hydrologic Criteria and Drainage Manual (1990). The methodology in the manual was developed for Southern Nevada by Clark County and the U.S. Army Corps of Engineers, Los Angeles District. Flood assessments conducted in Clark County following methods in the CCRFCD have been accepted by FEMA. The proximity of Area 5 to Clark County, and their similar physical and climatic characteristics, support use of this region-specific method for Area 5. Three potential flood hazards were identified in the area: alluvial fan flooding, shallow channelized flow, and sheetflow.

The southwest corner of the Area 5 RWMS is within the 100-year flood hazard Zone AO of the Barren Wash alluvial fan and within the 100-year flood hazard Zone AO of a channel that flows into the southwest corner of the Area 5 RWMS along the southern boundary of Halfpint alluvial fan (Figure 9). At this location, Zone AO of the alluvial fan and Zone AO of the channel are partly coincident. Zone AO of the fan is characterized by an average 100-year flood depth of one foot (ft) and flow of three $\mathrm{ft}$ per second. Zone AO of the channel is characterized by a 100-year flood depth of two feet. The remainder of the Area 5 RWMS is not within the 100-year flood hazard zone of either the Barren Wash fan, the Halfpint Range fan, or the Scarp Canyon fan, but is within flood hazard Zone X of these fans. The average 100-year sheetflow depth associated with Zone $\mathrm{X}$ is less than one $\mathrm{ft}$. The flood assessment determined that the southwest corner of the Area 5 RWMS is located within the 100-year flood hazard zone of an alluvial fan. In addition, this same corner is also located within the 100-year flood-hazard zone of a channel that impacts the southwest corner of the Area 5 RWMS. Sheetflow depths for a 100-year flood were less than one ft; therefore, sheetflow is not a hazard.

Although a substantial portion of the Area 5 RWMS is not located within a FEMA-designated 100-year flood-hazard zone, flood protection must be addressed for the facility. Currently, a perimeter dike/channel system is in place to protect the Area 5 RWMS from the 25-year, 24-hour flood hazard.

\subsubsection{Surface Water Protection}

The disposal site is located approximately $4 \mathrm{~km}(2.5 \mathrm{mi})$ northwest of the northern edge of Frenchman Lake (playa). Although Frenchman Lake does not meet the federal definition of a surface water, it does fit the state of Nevada definition, which includes dry lakes or playas.

Watersheds that drain toward the SWDS are normally dry and flow only in response to intense rainfall. Flow from the watersheds above the Area 5 RWMS is diverted around the SWDS by flood control structures located on three upstream sides of the RWMS (see Figure 6 and Appendix A). These structures have been constructed and certified to maintain a run-on control system capable of preventing flow onto the active portion of the Area 5 RWMS during peak discharge from a 25-year, 24-hour storm in accordance with Title 40 CFR 264.301(g), "Design and Operating Requirements.” The flood-control structures prevent external run-on. Internal drainage within the Area 5 RWMS perimeter is prevented from flowing into the unit by an 
earthen embankment that surrounds the three nonramped sides of the active disposal cell within the Area 5 SWDS. On-site precipitation is the only run-on that may enter the active cells. The unit is designed to collect and control this localized run-on, thus preventing runoff.

\subsubsection{Ground Stability}

The Area 5 RWMS meets the location and seismic standards for a RCRA permitted hazardous waste disposal site, as demonstrated in the NTS RCRA Part B Permit Application, volume 1, section B.3.a.1 (NNSA/NSO, 2005), and as approved by the NDEP through the issuance of interim status for the Pit 3 Low-level Mixed Waste Disposal Unit located in the Area 5 RWMS. The following information is from the NTS RCRA Part B Permit Application:

The southwestern United States, including Nevada, is tectonically active as compared with other parts of the country (40 CFR 264, Appendix VI). Natural seismic risk is moderate in the NTS region.

In summary, no known surface-cutting faults that have had displacement during Holocene time are present within $915 \mathrm{~m}$ (3,000 ft) of the RWMS (40 CFR 264.18). Trench excavations and mapping, large-scale $(1: 6,000)$ air-photo analysis, and surficial-deposit mapping were performed to evaluate a lineament located within $61 \mathrm{~m}$ (200 ft) of the RWMS. These investigations show that this lineament is not a surface-cutting fault or Holocene tectonic feature.

\subsection{Types, Quantities, and Sources of Waste}

The disposal site will be used as the sole depository of permissible and special waste that has been identified in the Waste Characterization Plan (Section 6.0). These wastes will be:

- Generated by entities that have been approved by the NNSA/NSO as described in the approval process section of the NTSWAC

- Other waste on a case-by-case approval by NDEP/BFF

Accurate records are available to indicate the total amount of regulated special waste (ALLW and hydrocarbon-burdened waste) that has been disposed since the first regulated special waste was disposed in September 1997. This additional horizontal expansion keeps all regulated ALLW in one area of the site (since Pit 7 is adjacent to Pit 6 Upper Cell and the to-bedetermined expansion area to the east of Pit 7). The projected waste requirements through 2007 reflect that it is highly unlikely that more than one additional regulated ALLW pit will be required.

For the period ending December 31, 2001, regulated ALLW accounted for 93 percent of the waste, with a total of $2,810.58 \mathrm{yd}^{3}$ (822.08 tons) and regulated special waste (hydrocarbonburdened waste) accounted for 7 percent, with a total of approximately $19.39 \mathrm{yd}^{3}$ (9.56 tons). The vast majority of waste proposed for disposal in the SWDS will meet the definition of ALLW as defined in Section 6.2.1. The total proposed capacity is 33,868 $\mathrm{yd}^{3}$ (pit 7, 5,831 $\mathrm{yd}^{3}$; and Pit 6, $28,037 \mathrm{yd}^{3}$ ). 


\subsection{Geology}

The following sections of the "Regional Geology" and the "Geology of Frenchman Flat and the Area 5 RWMS” are excerpts from the Nevada Test Site Waste Management Facilities Safety Analysis Report (Bechtel Nevada [BN], 2000).

\subsubsection{Regional Geology}

Basin and Range Physiographic Province mountains (Figure 10) are primarily Proterozoic and Paleozoic sedimentary rocks, largely of marine origin (Figure 11). These sedimentary rocks were folded and faulted during multiple periods of deformation and, in the western part of the Basin and Range Province, were intruded by granitic rocks of Mesozoic age (Stewart, 1978; 1980). The Proterozoic and Paleozoic sedimentary rocks and the Mesozoic intrusions underwent erosion during the early Cenozoic Era. This period of erosion was followed by extensional faulting of the older rocks in the Basin and Range Province, resulting in the structure definitive of the Province (Cole et al., 1989). Volcanic rocks, consisting of silicic tuffs and lavas, and basaltic lavas were erupted in the Province during the middle Cenozoic Era. The resulting southwest Nevada volcanic field is comprised of no less than seven large and partially overlapping calderas. These calderas are partially coincident with the mesas in the northwestern part of the NTS. Volcanic activity decreased dramatically during the late Miocene within the southern portion of the Basin and Range Physiographic Province. During the late Miocene to the Quaternary, volcanism was limited to minor basaltic flows.

Crustal extension, folding, and faulting continue in the Basin and Range Province to the present. There is evidence that Basin and Range crustal extension occurred in at least two stages across the NTS. The early phase, about 16 to 14 million years (Ma), consisted of high-angle northwestand northeast-trending normal faults, whereas the later phase (post-11 Ma) consisted of slightly steeper dipping north-south trending normal faults. The earlier phase is thought to be responsible for several minor topographical troughs discernable on isopach maps of older ashflow units and for the recently reinterpreted low-angle faults in the Mine Mountains area (Cole et al., 1989). The later phase precipitated the present basin forming faults (Dockery-Ander, 1984). Erosion of the uplifted mountain ranges has progressively filled the basins at the NTS with [a depth] as much as 1,200 meters (3,940 ft) of gravel, sand, and silt (Laczniak et al., 1996).

\subsubsection{Geology of Frenchman Flat and the Area 5 RWMS}

The Area 5 RWMS is located in northern Frenchman Flat at the juncture of three coalescing alluvial piedmonts (Snyder et al., 1995) (Figure 12). Frenchman Flat is a hydrologically closed basin located along the southeastern boundary of the NTS. The basin is bounded by the Halfpint Range to the north, the Ranger Mountains and Buried Hills to the east-southeast, Mount Salyer to the west, and Mercury Ridge and Red Mountain to the south. The mountains on the south and east consist primarily of limestone and clastic rocks of Paleozoic age, and on the north and west by volcanic rocks of Miocene age (Frizzell and Shulters, 1990). In northern Frenchman Flat, the Miocene volcanic and underlying pre-Tertiary rocks that demarcate the basin are broken by numerous normal faults, resulting in fault blocks that are gently to moderately tilted. Although regional Miocene tectonism began earlier, at least the northern portion of Frenchman Flat formed at some time after deposition of middle Miocene volcanic rocks with an estimated age of about 11.5 Ma (Sawyer et al., 1990), but before intrusion of basaltic dikes along some of the faults about 8.5 Ma (Crowe et al., 1983). Extension has continued into the Holocene, as evidenced by 
movement along Cane Spring fault along the western margin of the basin, and Rock Valley fault along the southern margin of the basin (Carr, 1984).

Surface and subsurface geologic investigations were performed in northern Frenchman Flat as part of the site characterization activities for the Area 5 RWMS. A detailed description of the surficial geology and soils of northern Frenchman Flat is presented in Raytheon Services Nevada, 1995.

\subsection{Hydrogeologic Characteristics}

The following sections are excerpts from the Nevada Test Site Waste Management Facilities Safety Analysis Report (BN, 2000).

\subsubsection{Subsurface Hydrology}

The groundwater systems beneath the NTS have been summarized in a number of studies including Laczniak et al. (1996), Winograd and Thordarson (1975), and Blankennagel and Weir (1973). One recurring observation within these studies is that accurate characterization of the NTS groundwater flow systems is difficult because of limited data (few wells penetrate more than $33 \mathrm{~m}$ [100 ft] into saturated ground at Yucca Flat), effects caused by nuclear testing (fracturing and groundwater mounding), and the general complexity of the hydrogeology of the region. Laczniak et al. (1996) provide the most complete and recent summary of the groundwater systems of the NTS; therefore, the following overview of regional and local groundwater systems is taken from Laczniak et al. (1996). Characterization of vadose zone properties and processes was drawn from investigations of Frenchman Flat and Yucca Flat (Levitt et al., 1996; BN, 1998).

\section{Regional Groundwater System}

The NTS is located within the Death Valley groundwater flow system, one of the major hydrologic subdivisions of the southern Great Basin. The Death Valley groundwater flow system covers an area of about 40,920 square kilometers $\left(\mathrm{km}^{2}\right)\left(15,800\right.$ square miles $\left.\left[\mathrm{mi}^{2}\right]\right)$ and consists primarily of volcanic rock in the west and carbonate rock in the east. This flow system is estimated to transmit more than 86 million $\mathrm{m}^{3}$ (70,000 acre-ft) of groundwater annually. Most of this flow moves through a thick sequence of Paleozoic carbonate rock extending throughout the subsurface of central and southeastern Nevada and is sometimes referred to as the central carbonate corridor.

Winograd and Thordarson (1975) characterized the major water-bearing units of the NTS. Laczniak et al. (1996) revised these units into five general designations:

- The basement confining unit

- The carbonate-rock aquifer

- The eleana confining unit

- The volcanic aquifers and confining units

- The valley-fill aquifer

Although each of these units has internal variations and complexities, and different regions are influenced by different combinations of these units, the five designations provide a simple, yet accurate overview of the subsurface hydrogeology. 


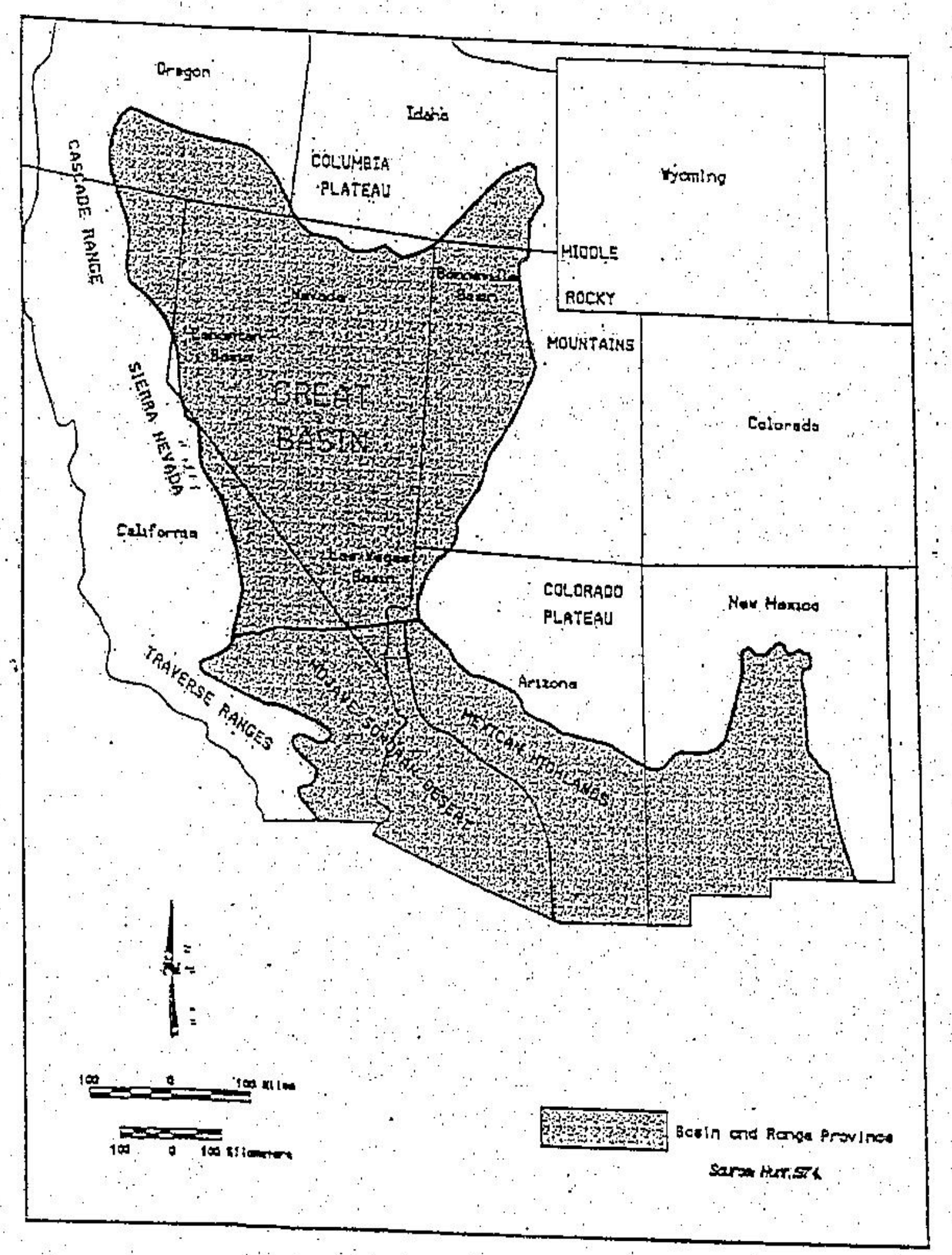

Figure 10: Basin and Range Physiographic Province 


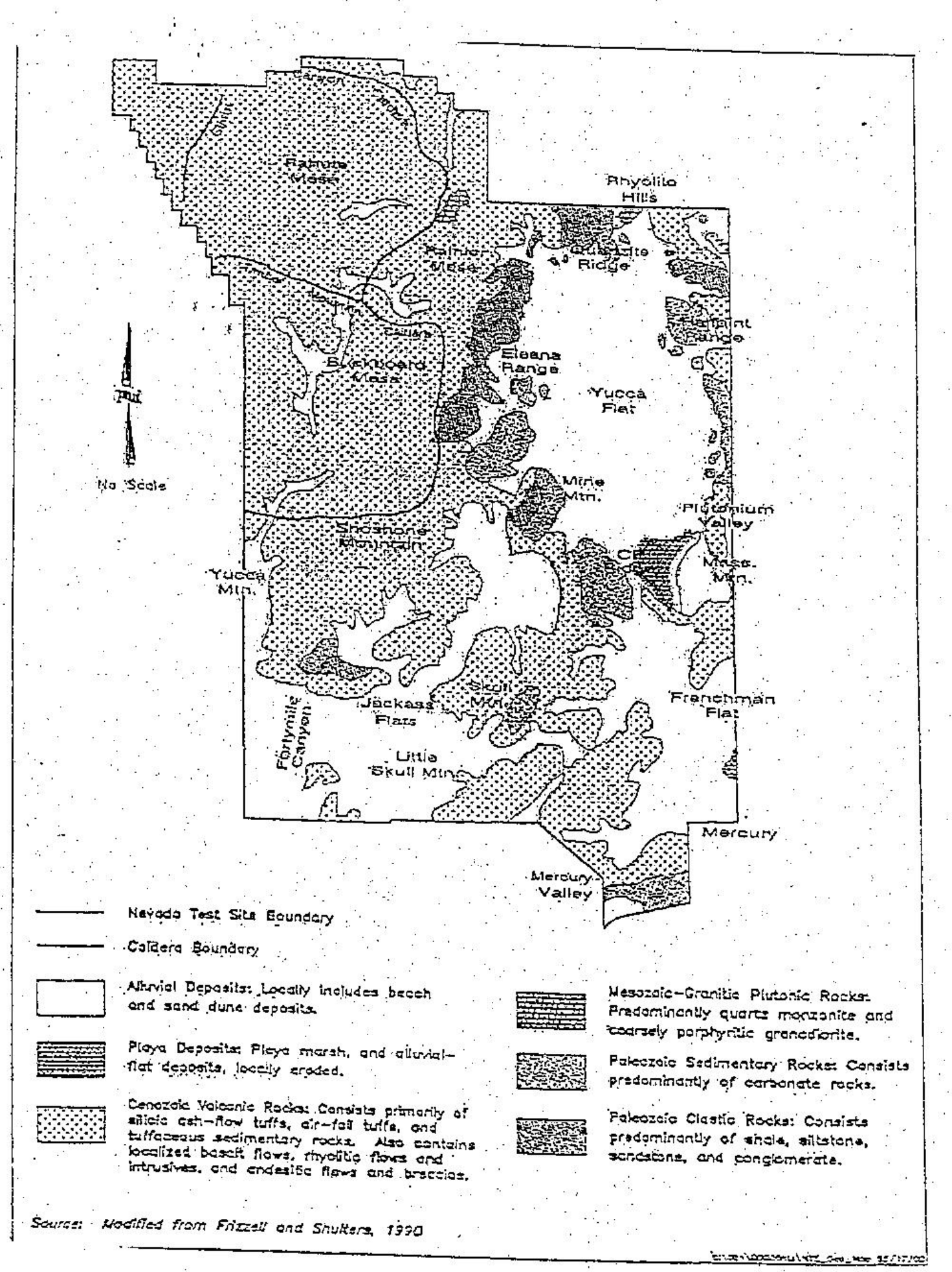

Figure 11: Geologic Map of the Nevada Test Site (Proterozoic and Paleozoic Sedimentary Rocks) 


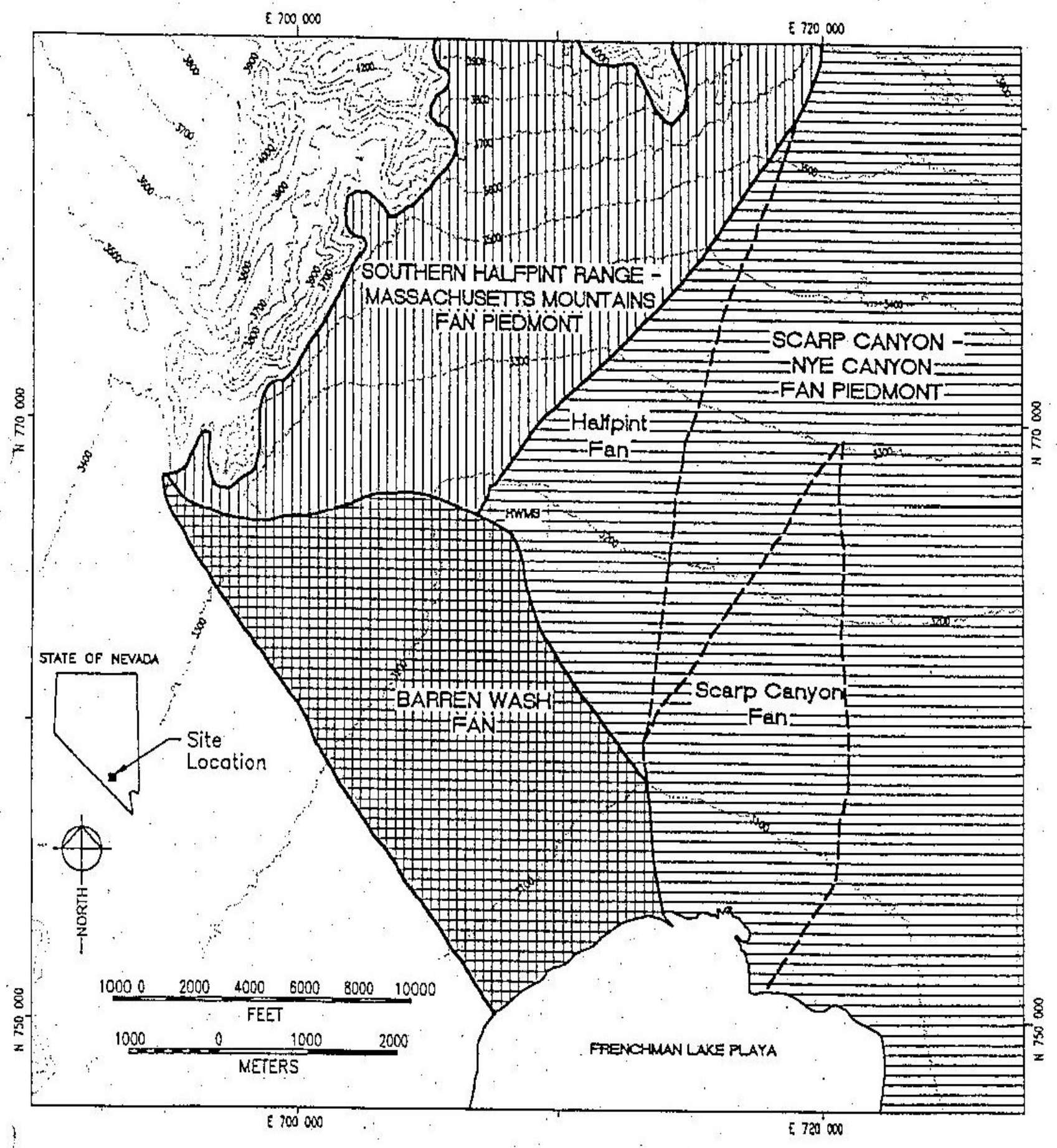

Figure 12: Major Landforms of Northern Frenchman Flats, NTS

(Snyder et al.,1995) 
The divisions of different groundwater flow systems within the NTS are based on the concept of groundwater subbasins, defined as the area that contributes water to a major surface discharge. Three principal groundwater subbasins (Figure 13) have been identified within the NTS region as the Ash Meadows, Oasis Valley, and Alkali Flat-Furnace Creek Ranch subbasins. However, the boundaries between these subbasins are not well defined and are the subject of current debate.

The Ash Meadows subbasin covers an area of about 10,360 $\mathrm{km}^{2}\left(4,000 \mathrm{mi}^{2}\right)$ and includes Yucca Flat and Frenchman Flat (Figure 13). Precipitation is believed to recharge the subbasin along its northern boundary at the Belted, Reveille, Timpahute, and Pahranagat Ranges; along its eastern boundary at the Sheep Range; and along its southern boundary at the Spring Mountains. Recharge is also suspected to occur within the subbasin at higher elevations of the Spotted, Pintwater, and Desert Ranges. Groundwater primarily flows through the lower carbonate-rock aquifer and discharges along a line of springs in Ash Meadows.

Groundwater flow rates through the Ash Meadows subbasin are highly variable; estimates range from less than 0.3 to more than $300 \mathrm{~m} /$ day ( 1 to 1,000 ft/day), depending on the unit. In general, the regional carbonate-rock aquifer is believed to transmit water at the fastest rate, whereas the basement and Eleana confining units transmit water at the slowest rate, and volcanic and valleyfill aquifers and confining units transmit water at intermediate rates.

\section{Frenchman Flat Groundwater}

Frenchman Flat lies within the Ash Meadows groundwater subbasin. In the Frenchman Flat area, three hydrostratigraphic units have been reported, but not confirmed. The uppermost unit is the Quaternary and Tertiary valley fill, the intermediate unit is the Tertiary volcanic ash and lava flows, and the Paleozoic carbonate is the lowermost unit. The following discussion presents a simplified view of the three units.

The depth to water at the Area 5 RWMS unit ranges from approximately $235 \mathrm{~m}$ (773 ft) to $272 \mathrm{~m}$ (892 ft) below the surface, based on measurements recorded at three pilot wells (UE5PW-1, UE5PW-2, and UE5PW-3) developed as part of site characterization activities. The pilot wells are located in a triangular array near the southeast, northeast, and northwest corner of the Area 5 RWMS. The elevation of the groundwater under the site is approximately $734 \mathrm{~m}(2,407 \mathrm{ft})$. Depth to water is the least in the playa lake area (approximately $3.5 \mathrm{~km}$ [1.5 mi] south of the Area $5 \mathrm{RWMS})$ at $213 \mathrm{~m}(700 \mathrm{ft})$ below the surface.

The characteristics of the uppermost stratigraphic unit, the Quaternary and Tertiary valley fill, directly affect possible release paths from the Area 5 RWMS and the Hazardous Waste Storage Unit. This stratigraphic unit is composed of alluvial and colluvial materials that formed in an alluvial fan environment. The depth of the valley fill ranges from $183 \mathrm{~m}(600 \mathrm{ft})$ on the northwest corner to greater than $305 \mathrm{~m}(1,000 \mathrm{ft})$ on the southeast corner. The valley fill is connected hydraulically to the Tertiary volcanic ash and lava flows. 
The lower hydrostratigraphic unit, the Paleozoic carbonate rocks, could be hydraulically connected with the upper Cenozoic hydrogeologic units, but the water levels in the carbonate are 3 to $9 \mathrm{~m}$ (10 to $30 \mathrm{ft}$ ) lower than the levels in the Cenozoic units.

\subsubsection{Area 5 Vadose Zone}

The alluvium and the unsaturated portions of the tuff constitute the vadose zone at the Area 5 RWMS. The vadose zone beneath the Area 5 RWMS is the primary barrier between the site and the uppermost aquifer. Four investigations have described the physical, chemical, and hydrologic properties of the vadose zone at the Area 5 RWMS. Spatial variation in properties up to a depth of $9 \mathrm{~m}$ (29.5 ft) have been investigated in existing excavations (pits and trenches) at the Area 5 RWMS (Reynolds Electrical \& Engineering Co., Inc. [REECo], 1993a). The properties of core and cutting samples of the near-surface vadose zone to a depth of $37 \mathrm{~m} \mathrm{(121} \mathrm{ft)} \mathrm{have} \mathrm{been}$ reported for nine Science Trench Boreholes (REECo, 1993b) and four additional Science Boreholes (Blout et al., 1995). The properties of core and cutting samples of the deep vadose zone to $291 \mathrm{~m}$ (955 ft) deep have been described during the Pilot Well Study (REECo, 1994). The location of these wells and trenches is shown in Figure 14.

\subsection{Climate}

The following descriptions of the climate are excerpts from the Nevada Test Site Waste Management Facilities Safety Analysis Report (BN, 2000).

\subsubsection{Regional Climate}

The NTS lies within a region of the southwestern United States known for its arid intermountain deserts. Humid Pacific air masses rising over coastal mountain ranges to the west cause most of the moisture to fall on the intercoastal mountain ranges before reaching the interior of the NTS. The NTS lies in a region that is transitional between the south-central Great Basin and the Mojave Desert. The climate is characterized by a large number of cloudless days, low precipitation, and high daily temperatures during the summer (Hunt et al., 1966).

\subsubsection{Precipitation}

The climate of Frenchman Flat is arid. The majority of rain falls during two seasons, with a larger amount occurring in the winter and a smaller amount occurring during the summer months. The average annual precipitation, based on a 37-year record at a station located $6.4 \mathrm{~km}$ (4 mi) southwest of the WEF, is $126 \mathrm{~mm}$ per year (5.0 in per year). Average annual evapotranspiration at the Area 5 RWMS is 1,620 mm (64 in). This is about 13 times the annual average precipitation (DOE/NV 2000).

\subsubsection{Temperature}

Air temperatures at the NTS vary highly with the seasons. Large daily fluctuations are common, especially on the playas and valley floors. Typical daily air temperature ranges for the RWMS range from -3 to 12 degrees Celsius $\left({ }^{\circ} \mathrm{C}\right)$ (27 to 54 degrees Fahrenheit [ $\left.{ }^{\circ} \mathrm{F}\right]$ ) in January, and from 17 to $36^{\circ} \mathrm{C}\left(63\right.$ to $\left.97^{\circ} \mathrm{F}\right)$ in July (Magnuson et al. 1992). 


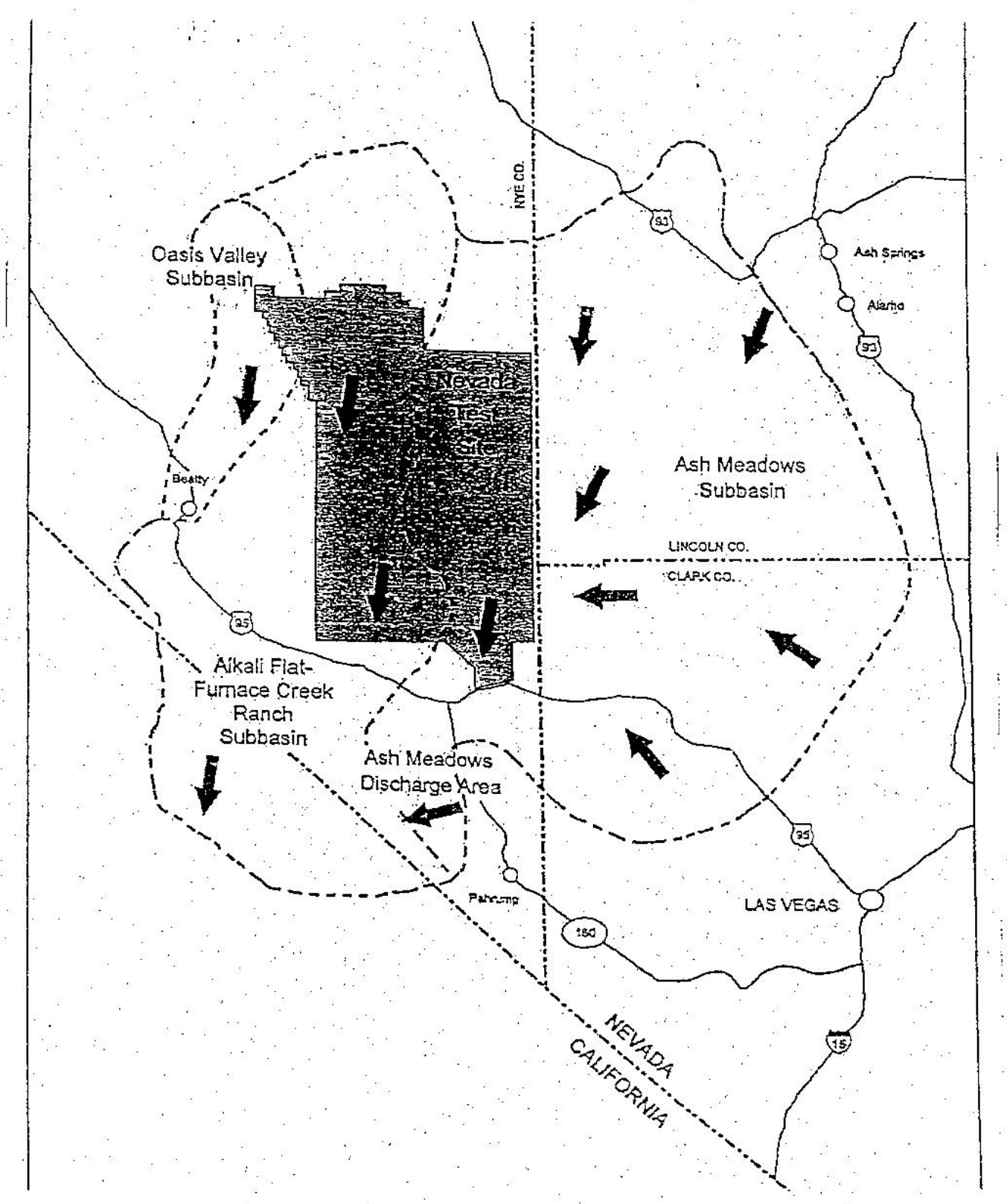

29

Figure 13: Groundwater Hydrologic Units of the NTS and Vicinity 

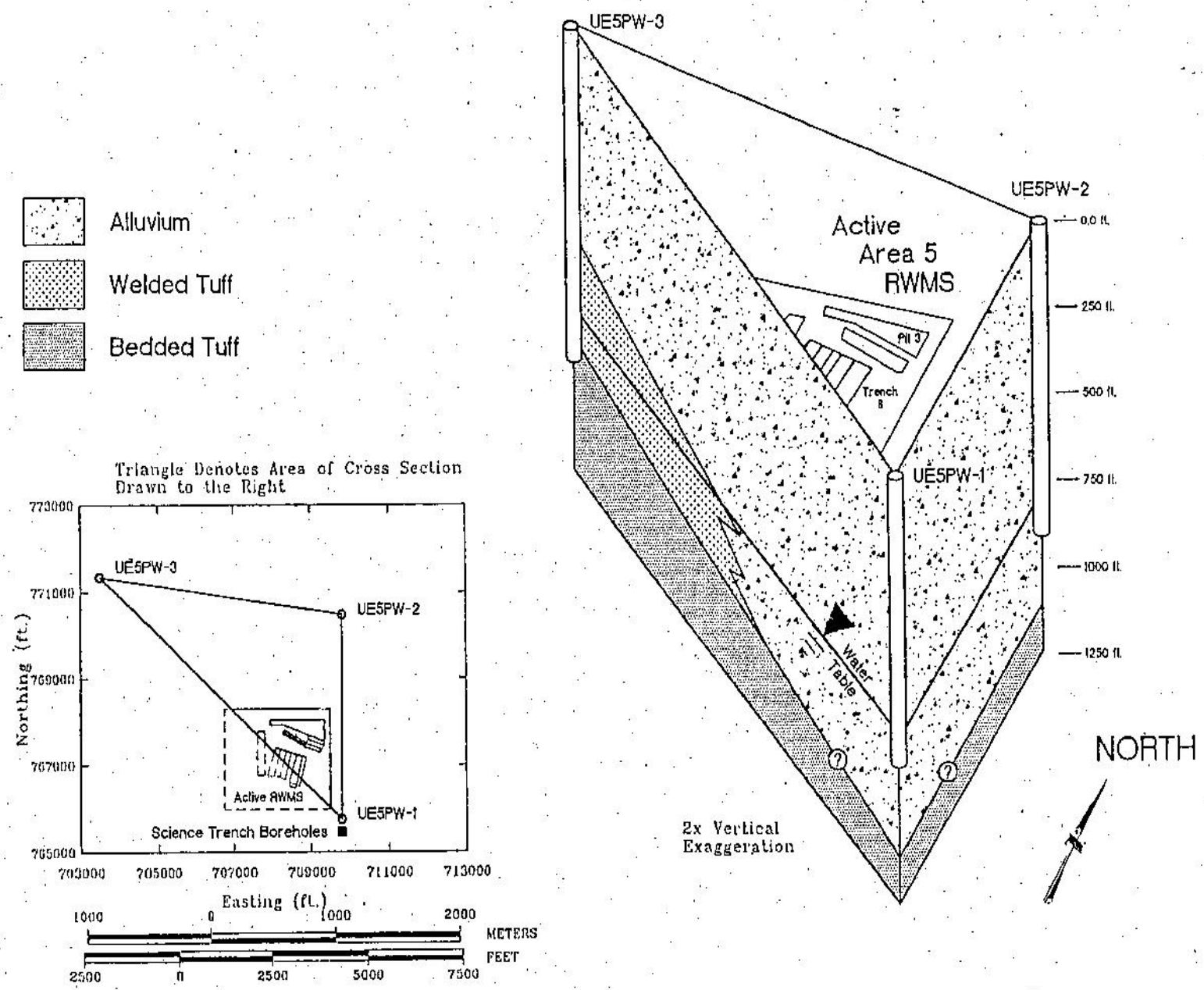

Figure 14: Map Showing the Pilot Wells in Relations to the Area 5 RWMS with Geologic Cross Section Interpreted from Core and Drill Cuttings 


\subsubsection{Wind}

Global pressure systems, mountain ranges, and site-specific topography influence wind direction on the NTS (Quiring, 1968). At the RWMS, low wind speeds tend to originate from the north, whereas high wind speeds tend to originate from the south (DOE/NV, 2000). Northern winds tend to dominate in the winter and southern winds dominate in the summer. Localized differential heating of the land surface during the day, coupled with a topographic trend toward greater elevation in the northern section of the NTS, result in southern winds flowing up-slope during the day and northern winds moving down-slope at night. Wind speeds tend to be greater in the spring than in the fall. Wind rose diagrams illustrate wind direction (direction of wind source) and the occurrence of wind speed groupings in each direction, using hourly wind data measured at a height of $3.0 \mathrm{~m}(10 \mathrm{ft})$ above the ground surface (DOE/NV, 2000). The Area 5 meteorology station is located southeast of the Area 5 RWMS, and approximately $100 \mathrm{~m}(328 \mathrm{ft})$ from the groundwater pilot well UE5PW-1. The Area 5 Hypsometer meteorology station is located approximately $400 \mathrm{~m}(1,312 \mathrm{ft})$ southwest of the Area 5 RWMS.

Figure 15 summarizes the annual wind rose at Well 5B in Frenchman Flat, indicating that the winds are predominately from the southwest, varying from 0 to 20 meters per second (m/s).

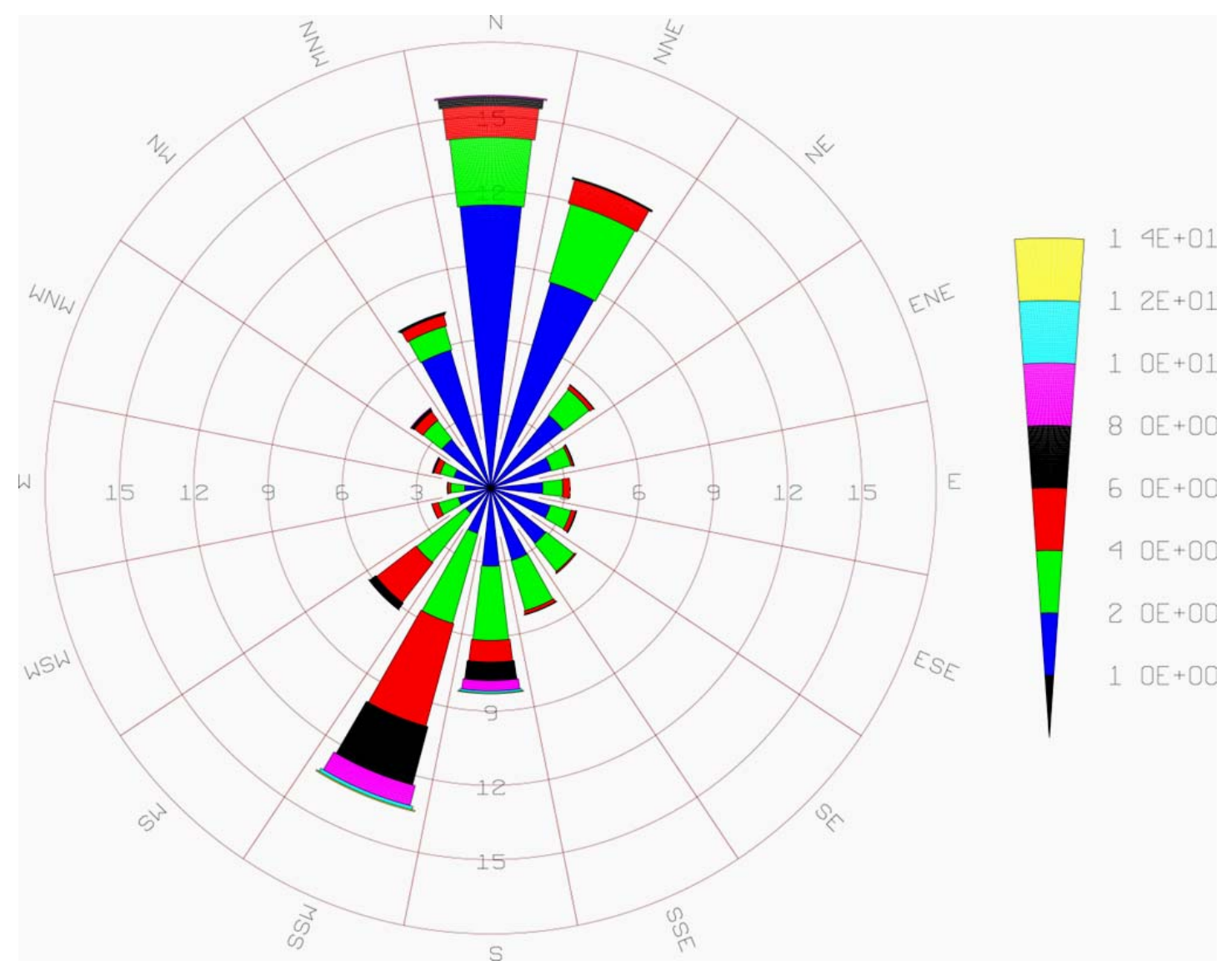

Figure 15: Wind Rose Diagram for the Area 5 RWMS (units in m/s) 


\subsection{Run-On and Runoff Control}

Washes that drain toward the Area 5 RWMS are normally dry and flow only in response to intense rainfall. Flow from the watersheds above the Area 5 RWMS is diverted around SWDS by flood control structures located on three upstream sides of the Area 5 RWMS. These structures have been constructed and certified to maintain a run-on control system capable of preventing flow onto the active portion of the Area 5 RWMS during peak discharge from at least a 25-year, 24-hour storm in accordance with Title 40 CPR 264.301(g). Internal drainage within the Area 5 RWMS perimeter is prevented from flowing into the unit by an earthen embankment that surrounds the three nonramped sides of each pit. Onsite precipitation is the only run-on that may enter the active cells. The unit is designed to collect and control this localized run-on, thus preventing runoff.

\subsection{Water Monitoring Plan}

\subsection{Groundwater Monitoring}

Because the SWDS is located inside the Area 5 RWMS, and three monitoring wells located outside the Area 5 RWMS are currently used to monitor the groundwater for RCRA compliance, no additional monitoring activities are planned for this nonhazardous waste disposal site. The details of these monitoring activities are located as Exhibit P.2.e-1 in Volume III of the RCRA Part B Permit Application for Waste Management Activities at the Nevada Test Site. In addition, this SWDS receives less than 20 tons of waste per day based on a yearly average, and is located in a region that receives less than 62.5 centimeters (25 inches) of rain per year.

\subsection{Operating Plan}

\subsection{Collection and Transportation}

RWP/RWO personnel will be responsible for the day-to-day operation and maintenance of the disposal site. The generator will be responsible for preparation of appropriate documentation required by the NTSWAC, as well as the transportation of the waste.

\subsection{Personnel}

The following organizations, personnel, or their designees are responsible for waste stream approval, transporter approval, disposal packet approval, and shipment refusal:

- Waste stream approval and shipment authorization - NNSA/NSO Assistant Manager for Environmental Management

- Transporter approval - waste generator facility

- Disposal packet approval - NSTec RWP/RWO Facilities Supervisor, or designee

- Shipment refusal - NSTec/RWP/LLW Project Manager, or designee

Personnel who will staff the SWDS operations are those who are trained to conduct operations at the Area 5 RWMS. Personnel are trained to verify that each shipment meets the requirements of the NTSWAC (current revision). 
Training includes, but is not limited to, Hazardous Waste Site General Worker training (as required by Title 29 CFR 1910.120, "Hazardous Waste Operations and Emergency Response”), Radiation Worker II training (as mandated by Title 10 CFR 835, “Occupational Radiation Protection"), and Hazard Communication Training (as mandated by Title 29 CFR 1910.1200). In addition, personnel participating in asbestos disposal operations will be given an annual Asbestos Awareness Training, Title 29 CFR 1910.1001, “Asbestos”).

\subsection{Processing In}

Waste may only be processed in while disposal site operators are present. At Gate 100, the driver will be badged for entry onto the NTS. At the Area 5 RWMS, the transporter must check in through the main office. Shipping documents and records will be reviewed at this time to verify that this is an authorized shipment for disposal in the SWDS.

\subsection{Off-Loading}

If any container is found to be damaged or breached during inspection, off-loading, or disposal, the container will be placed on a plastic sheet (or equivalent) in the staging area to minimize the spread of contamination; evaluated by the RWP/LLW Program Manager, or designee; and corrective action will be implemented. Examples of corrective action may include:

- Patching the container

- Taping plastic sheets to wood containers

- Overpacking,

- Placing damaged, but unbreached, containers on the uppermost disposal tier

Waste material containers are to be stacked in an orderly manner to prevent an unsafe working face of the stack. Boxes are stair-stepped, to the extent practicable, to prevent them from falling forward (Figure 16), and drums are nested so as to prevent roll-aways. Figure 17 illustrates a typical profile configuration through a typical disposal unit at the Area 5 RWMS. The arrangements shown in the two figures are only examples. Actual configuration may vary as determined by RWO personnel. Waste containers will be stacked in the SWDS in such a manner that all portions of each package are approximately $1.2 \mathrm{~m}(4 \mathrm{ft})$ below the natural grade. In addition, the location of each container will be recorded in the LLW Information System database.

\subsection{Operations Log}

An Operations log will be maintained to indicate the following:

- Each load of waste that is disposed, including date, time, tractor number, trailer number, generator, shipment number, pre-entry radiation readings, waste type and waste stream identification, waste package types, and departure time

- Identification of personnel entering the disposal site (accomplished through the access register at the main office)

- Routine disposal site activities

- Nonroutine events such as unforeseen circumstances. 
Note: The number of tiers is dependent upon the pit depth.

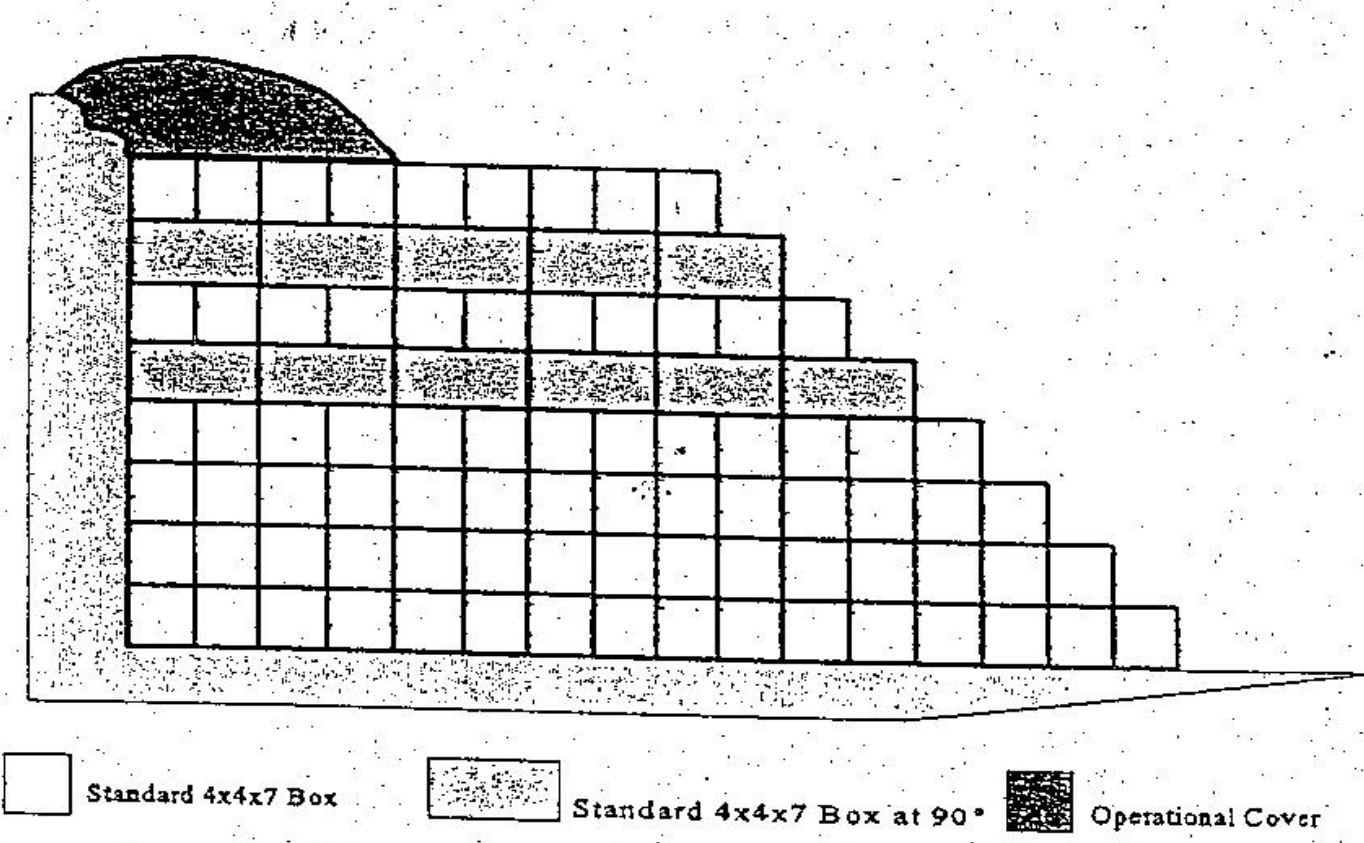

Boxes are rotated $90^{\circ}$ every other tier, stanting with the fiftin tier, or as needed.

Figure 16: Side View of Working Face (example only) 


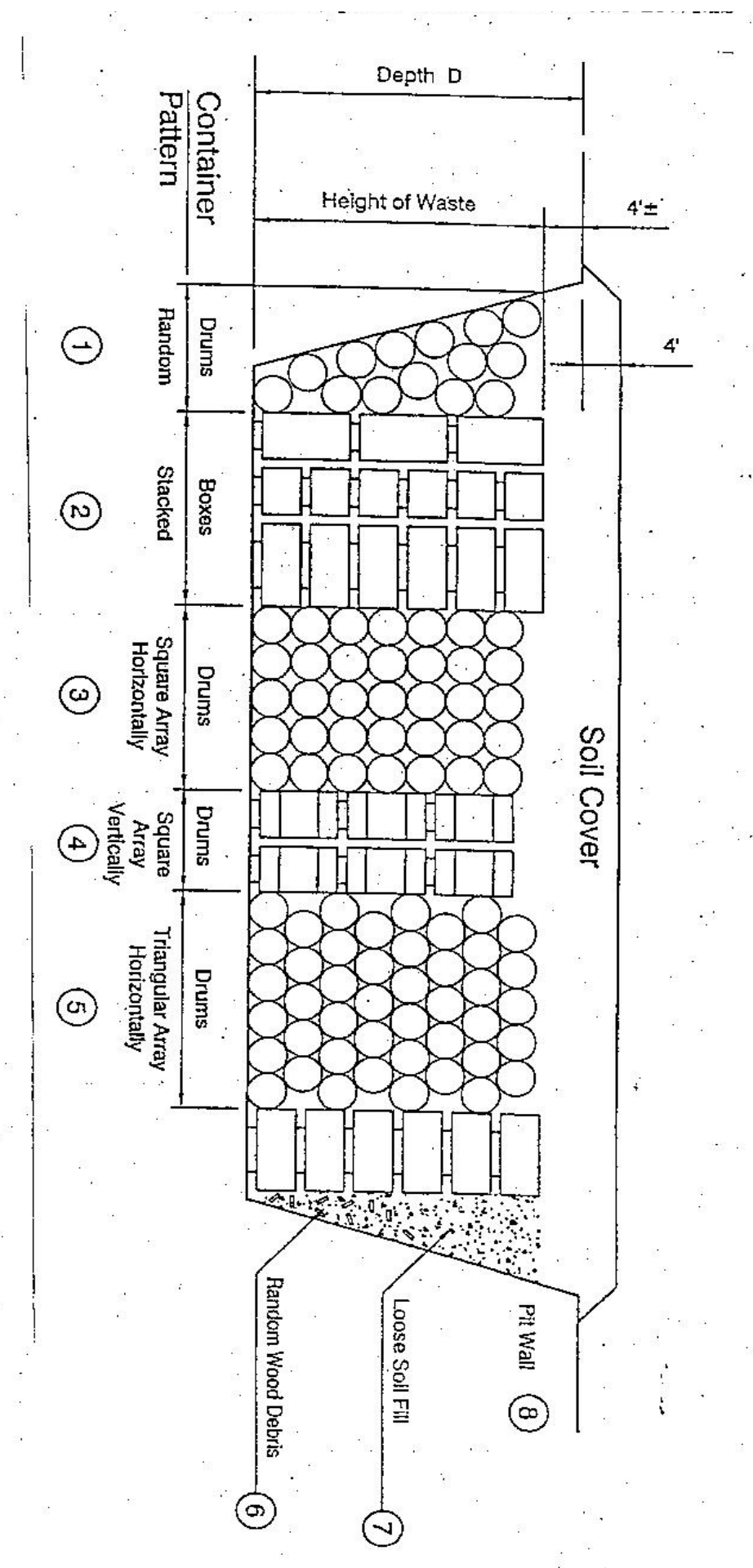

Figure 17: Profile of a Typical Disposal Unit at the Area 5 RWMS 


\subsection{Inspections}

All waste packages are inspected for leaks and integrity as they are unloaded. In addition, an inspection of the site is conducted weekly. The inspection will consist of the following:

- Erosion of the run-on control structures

- Settling of the covered material

- Condition of fencing and signs

- Housekeeping

Corrective measures will be taken as soon as possible to correct the deficiency. All corrective measures and their completion dates will be recorded. Records will be kept onsite for the current year as well as the previous year.

\subsection{Signage/Hours of Operation}

A sign is posted at the entrance to the disposal site that informs personnel of an emergency contact telephone number. This is not a publicly accessible waste disposal site, and waste disposed is subject to prior scheduling and approval. The site is normally open only during the day shift of the normal work week (currently Monday through Thursday, excluding holidays; however, it is possible to make special arrangements for nonscheduled workdays). Approved generators are informed of the hours that waste may be received at the Area 5 RWMS. A fee schedule is provided to the waste generators in advance of waste shipment. Access is controlled through the main Area 5 RWMS office. A sign at the entrance of Area 5 SWDS active cell(s) indicates that an asbestos dust hazard may be present. The barrier to the active cell(s) remains locked when the cell is not occupied. The site is protected from intrusion by a secured entry gate and a fence completely surrounding the site. In addition, the entire RWMS is also surrounded by a secured fence.

\subsection{Disposal Site Equipment}

The equipment used at the disposal site consists of a forklift, a front-end loader, a crane, a water truck, and a motor grader. Other types of equipment that may be used at the disposal site on an irregular basis include compactors and rollers. Equipment will be deployed on an as-needed basis and may be in addition to those described above.

\subsection{Operating Records}

Records will be maintained by designated disposal site personnel. The following documentation must be present with each load of waste:

- A Bill of Lading or Load Verification documentation

- Weigh ticket or weight identified by another method

- Asbestiform Shipment Notification (for regulated ALLW)

Prior to acceptance, the disposal site operator will ensure that all documentation is complete, accurate, and legible. If the documentation is not acceptable, the load may be rejected. The waste may also be rejected if, upon inspection, it is determined that it does not conform to NTSWAC or is inadequately represented.

The amount and source of waste delivered will be documented in the operating record. 
Additional documentation required as operating records are Access Records and Inspection checklists. All shipments disposed in the SWDS will be recorded in the Area 5 RWMS database for an indefinite period. Hard copy records will be stored for at least two years at the Area 5 RWMS office. After this period, records will be archived at a designated facility. These records include the following information:

- Name, address, phone number of waste generator and waste transporter

- Quantity of waste disposed in cubic meters or cubic yards and date of receipt

- Asbestiform Shipment Notification (for regulated ALLW), which includes net weight, net volume, and a certification statement that the wastes in the shipment are those authorized by NNSA/NSO

- Bill of lading or shipping manifest with date of departure, number of containers, and type of each container

- Other paperwork required by the NTSWAC (e.g., Certification Statements and Package Storage and Disposal Forms)

\subsection{Cover and Lift Control}

Waste containers will be stacked in the SWDS in such a manner that all portions of each package

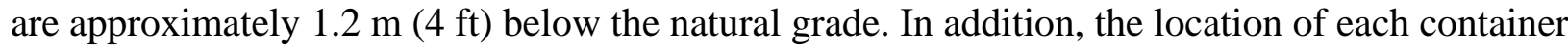
will be recorded in the LLW Information System database. Five complete rows, or

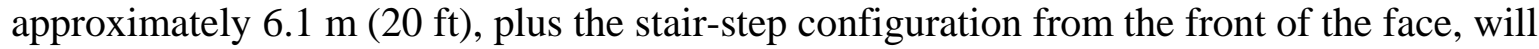
always be exposed (not covered and not trafficable), ensuring a stable working surface for equipment placing the operational cover material. The operational cover consists of native soils from the spoils pile.

The packaging requirements (use of steel drums, lined wooden boxes, steel boxes, or Sealand ${ }^{\circledR}$ containers) prevent asbestos dust from being released into the air and meet the intent of state regulatory requirements for daily cover to control disease vectors, fire, odors, and blowing litter. An operational cover with a minimum of $2.4 \mathrm{~m}(8 \mathrm{ft})$ will be placed on the packages. The operational cover will be graded such that run-on will be directed away from the open pit, and crowned to prevent pooling and infiltration.

\subsubsection{Cells/Compaction}

Soils used to fill void spaces between rows and for operational cover will consist of clean native soil obtained from areas near the disposal pit.

It is not expected that large quantities of combustible construction and demolition debris will be disposed in the site. Therefore, the requirements of NAC 444.652, "Disposal of Special Wastes: Construction and Demolition Wastes,” which require cross-sectioned cells separated by compacted cover material, are not applicable. 


\subsubsection{Operational/Temporary Cover}

Regulated ALLW, LLW, LLW containing PCBs, and LLHB waste is packaged inside steel drums, lined wooden boxes, steel boxes, or Sealand ${ }^{\circledR}$ containers. This prevents dust from being released into the air and meets the intent of state regulatory requirements for daily cover to control disease vectors, fire, odors, and blowing litter. An operational cover will be placed on the packages. The operational cover will be graded such that run-on will be directed away from the open pit, and crowned to prevent pooling and infiltration and to maximize evaporation of the water. Cracks, depressions, and erosion will be repaired promptly to maintain cover integrity.

\subsection{Dust Control}

Water trucks containing nonpotable water will be used to suppress dust on the compacted dirt roads, as necessary, and during operations involving compaction or production of cover material.

\subsection{Litter Control}

All material disposed in the SWDS will be containerized or packaged in such a manner that windblown material will not exist at this disposal site. This will ensure that the disposal site maintains an aesthetically pleasing environment. Scavenging and salvaging are not permitted in the disposal cell.

\subsection{Vector Control}

Because the regulated ALLW will be containerized, no vectors are anticipated.

\subsection{Fire Protection}

Open burning of solid waste is prohibited by NAC 444.6675, "Operating Criteria, Compliance with State Implementation Plan; Open Burning of Certain Solid Wastes Prohibited.” However, fires could be initiated through malfunctioning electrical devices or disposal site equipment. Fire extinguishers are located in the CAAB and on disposal site equipment.

In the event of a fire, the NTS Fire Department will be notified by calling 9-1-1 on the telephone or by using a "Mayday" signal on the NTS radio communication system. After making this notification, disposal site personnel may use hand-held fire extinguishers to control small fires. Under no circumstances will disposal site operators attempt to extinguish a large fire without instructions from the NTS Fire Department.

The fire station serving the disposal site is located approximately $24 \mathrm{~km}$ (16 mi) away and operates 24 hours per day, 7 days a week. In addition, another fire station is available in Area 6, approximately $21 \mathrm{~km}$ (13 mi) away, during normal working hours.

\subsection{Methane Gas/Explosive Gas Monitoring}

It is not anticipated that the waste and environmental media will generate methane gases. Based on the physical and chemical composition of the buried material and low annual rainfall at the disposal site, the generation and accumulation of explosive or toxic gases is considered minimal or nonexistent. Therefore, methane gas/explosive gas monitoring is not considered necessary during the active life of the SWDS, but will be evaluated at or after the time of closure. 


\subsection{Unforeseen Circumstances}

\subsubsection{Medical Emergency}

Emergency medical services are located in Area 6, approximately $21 \mathrm{~km}$ (13 mi) away, and are available during working hours. Disposal site personnel may contact Medical Services by calling 295-3490 or 9-1-1, or by using a "Mayday" signal on the NTS radio communication system.

\subsubsection{Natural Events}

The disposal site is protected from run-on water through flood protection structures and soil berms. However, rainfall directly on the site may result in muddy conditions which require that the site be closed for a short period of time until additional native soil is added to muddy areas to provide a workable surface.

\subsubsection{Equipment Failure}

Equipment at the disposal site will be maintained to prevent failure. However, there may be circumstances where equipment failure may occur; and the equipment cannot be repaired in a timely manner. Backup equipment (forklifts, loaders, scrapers, dozers, etc.) will be obtained from other NTS operations to provide an operational cover, as needed, while the equipment dedicated for the disposal site is being repaired.

\subsection{Solid Waste Report}

NNSA/NSO will submit a solid waste report to the NDEP (Las Vegas), for the preceding calendar year, by January 30 of each year. NNSA/NSO will include LLW, LLW containing PCBs, LLHB waste and regulated ALLW as separate items on the annual waste report. Information contained therein will include:

- Net weight of waste material

- A list of generators for the reporting period

- Deviations from the NTSWAC, associated with the regulated ALLW, LLW, LLW containing PCBs, and LLHB waste

\subsection{Closure Plan}

NDEP/BFF will be notified in writing of an intent to close the disposal site at least 15 days before beginning closure activities. Closure activities will commence within 30 days of written acceptance of the plan by NDEP/BFF and will be completed within 180 days after beginning the closure (assuming funding is immediately available). It is anticipated that the disposal site will

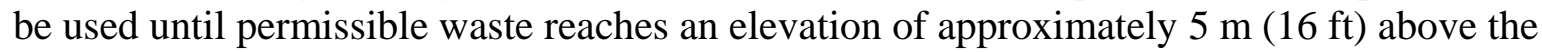
invert of each cell. The final design will incorporate a cap configuration that will have a slope of not less than 3 percent away from the center and be graded along the sides to drain surface water away from the disposal site.

The cover will consist of an infiltration layer containing a minimum $0.62 \mathrm{~m}$ (24 in) of earthen material having a capability that is less than or equal to the permeability of the natural subsoils. According to NAC 444.6891, "Requirements for Design and Construction of System for Final 
Cover," soil for the infiltration layer must not have a permeability greater than $1 \times 10^{-5}$

centimeters/second. Native soils for the area may require amending to ensure that they meet this performance standard. Geotechnical measurements will guarantee that the infiltration layer has met the specification requirements before completion of the final cover. An erosion layer, consisting of at least $15.2 \mathrm{~cm}$ (6 in) of native soil, will be placed on the infiltration layer. The erosion layer will be capable of sustaining the growth of native plants to stabilize the surface and reduce wind and water erosion.

An alternative design may be recommended at the time of closure that meets or exceeds infiltration requirements, controls erosion, maintains cover stability, and protects groundwater of the state of Nevada.

The closure plan will address all steps that will be taken to complete closure. This information will consist of a plan discussing the cover specifications; an estimate of the total volume of waste placed in the disposal site during its lifetime; decommissioning of any equipment or structures; and the installation of water, vadose zone, and/or gas monitoring devices, as required. The plan will meet all applicable regulations and will follow all relevant and appropriate regulations to the extent possible.

\subsection{Post Closure Plan}

The post closure program will:

- Maintain the integrity and effectiveness of the final cover

- Correct the effects of settlement, subsidence, erosion, or other circumstances that may affect the integrity of the final cover

- Demonstrate at closure that no leachate is present or demonstrate that any leachate does not pose a threat to public health and safety and the environment

- Evaluate the need to conduct groundwater monitoring, or demonstrate that any leachate does not pose a threat to public health and safety and the environment

- Evaluate the need to conduct gas monitoring, or demonstrate that any potential gas generation does not pose a threat to public health and safety and the environment.

The post closure program will be conducted for a period of 30 years. However, the land manager/operator maintains the right to request a waiver from the items listed above or request a waiver in the time period if it can be demonstrated that a less extensive program is sufficient to protect public health and safety and the environment. 


\subsection{References}

Bechtel Nevada, 2005. Nevada Test Site 2004 Waste Management Monitoring Report Area 3 and Area 5 Radioactive Waste Management Sites.

_ 2000. "Nevada Test Site Waste Management Facilities Safety Analysis Report" L-E10.311.HAA, Rev. 1, September 1998.

, 1998. Hydrogeologic Characterization of the Unsaturated Zone at the Area 3 Radioactive Waste Management Site. DOE/NV/11718-210. U.S. Department of Energy, Las Vegas, Nevada.

Blankennagel, R. K., and J. E. Weir, Jr., 1973. Geohydrology of the Eastern Part of Pahute Mesa, Nevada Test Site, Nye County, Nevada. U.S. Geological Survey Professional Paper 712-B. U.S. Geological Survey, U.S. Government Printing Office, Washington, D.C.

Blout, D. O., W. S. Birchfield, D. P. Hammermeister, and K. A. Zukosky, 1995. Site Characterization Data from the Area 5 Science Boreholes, Nevada Test Site, Nye County, Nevada. DOE/NV11432-170. U.S. Department of Energy, Nevada Operations Office, Las Vegas, Nevada.

BN, see Bechtel Nevada

Carr, W. J., 1984. Regional Structural Setting of Yucca Mountain, Southwestern Nevada, and Late Cenozoic Rates of Tectonic Activity in Part of the Southwestern Great Basin, Nevada and California. U.S. Geological Open-File Report 84-854, 109 pp.

Clark County Regional Flood Control District, 1990. Hydrologic Criteria and Drainage Design Manual. Las Vegas, Nevada.

Code of Federal Regulations, Title 29,Part 1910.120, “ Hazardous waste operations and emergency response,” 2004.

Code of Federal Regulations, Title 10, Part 835, “Occupational Radiation Protection,” 2005.

Code of Federal Regulations, Title 29, Part 1910.1200, “Hazard Communication,” 1994.

Code of Federal Regulations, Title 29, Part 1910.1001, “Asbestos,” 1995.

Code of Federal Regulations, Title 40, Part 264.301(g), “Design and Operating Requirements,” 2005.

Code of Federal Regulations, Title 40, Part 61, Subpart M “National Emission Standards for Asbestos,” 2002. 
Cole, J. C., R. R. Wahl, and M. R. Hudson, 1989. "Structural Relations Within the Paleozoic Basement of Mine Mountain Block: Implications for Interpretation of Gravity Data in Yucca Flat, Nevada Test Site.” In: C. W. Olsen and J. A. Carter (eds.), Proceedings of the Fifth Symposium on Containment of Underground Nuclear Explosions. Lawrence Livermore National Laboratory Proceedings, CONF-850953, pp. 431-456.

Crowe, B. M., M. T. Vaniman, and W. J. Carr, 1983. Status of Volcanic Hazard Studies for the Nuclear Waste Storage Investigations. Los Alamos National Laboratory Report LA-9325-MS, Los Alamos, New Mexico, 47 pp.

Dockery-Ander, H. A., 1984. Rotation of Late Cenozoic Extensional Stress, Yucca Flat Region, Nevada Test Site, Nevada. Ph.D. dissertation, Rice University, Houston, Texas, $77 \mathrm{pp}$.

DOE/NV, see U.S. Department of Energy, Nevada Operations Office

U.S. Department of Energy (DOE) Order 460.2A, “Departmental Materials Transportation and Packaging Management,” 2004.

U.S. Department of Energy, Nevada Operations, 2002. Nevada Test Site Waste Acceptance Criteria. NTSWAC, DOE/NV-325,Revision 4, February 2002.

Frizzel, J. A., Jr., and J. Shulters, 1990. Geologic Map of the Nevada Test Site, Southern Nevada. U.S. Geological Survey Miscellaneous Investigations Series Map I-2046, scale $1: 100,000$.

Hunt, C. B., T. W. Robinson, W. A. Bowles, and A. L. Washburn, 1966. Hydrologic Basin, Death Valley California. U.S. Geological Survey Professional Paper 494-B. U.S. Geological Survey, U.S. Government Printing Office, Washington, D.C.

Laczniak R. J., J. C. Cole, D. A. Sawyer, and D. A. Trudeau, 1996. Summary of Hydrogeologic Controls on Ground-Water Flow at the Nevada Test Site, Nye County, Nevada. U.S. Geological Survey Water-Resources Investigations Report 96-4109, 59 pp.

Levitt, D. G., C. F. Lohrstorfer, M. J. Sully, and J. M. Ginanni, 1996. “An Arid Zone Lysimeter Facility for Performance Assessment and Closure Investigations at the Nevada Test Site.” Proceedings, Waste Management, February 26-29, 1996, Tucson, Arizona.

Magnuson, S. O., S. J. Maheras, H. D. Nguyen, A. S. Rood, J. I. Sipos, M. J. Case, M. A. McKenzie-Carter, and M. E. Donahue, 1992. Radiological Performance Assessment for the Area 5 Radioactive Waste Management Site at the Nevada Test Site, Revision 1. Idaho National Engineering Laboratory, Idaho Falls, Idaho.

Miller, J. J., D. L. Gustafson, and S. E. Rawlinson, 1994. Flood Assessment at the Area 5 
Proposed Hazardous Waste Storage Unit, DOE/Nevada Test Site, Nye County, Nevada. Raytheon Services Nevada, Las Vegas, Nevada.

NAC 444.652 Disposal of special wastes: Construction and demolition wastes.

NAC 444.6665 Operating Criteria: Program for Detecting and Preventing Disposal of Regulated Hazardous Waste and PCB Wastes

NAC 444.6675 Operating criteria: Compliance with state implementation plan; open burning of certain solid wastes prohibited.

NAC 444.685 Financial Assurance

NAC 444.733 (9) Application for Permit to Operate Class III Site or Lateral Expansion Thereof

NAC 444.965-444.976 Transportation and Disposal

NAC 444.971 Standards for Handling and Transportation

NAC 444.972 (1) Approval Required for Transportation

NAC 444.972 (2) Submission of Information to Obtain Approval

NAC 444.973 Maintenance and Filing of Records Regarding Transportation

NAC 444.974 Notification required before delivery; disposal at site other than Class I disposal site.

NAC 444.974(2) Disposal of Asbestos

Quiring, R.F., 1968. Climatological Data, Nevada Test Site and Nuclear Rocket Development Station. ERLTM-ARL 7. U.S. Department of Commerce, Environmental Sciences and Services Administration.

Raytheon Services Nevada, 1995. Surficial Geology and Landscape Development in Northern Frenchman Flat-Interim Summary and Soil Data Report, DOE/Nevada Test Site, Nye County, Nevada. September 1995.

PLN-1013 Management Plan For The Disposal Of Low-Level Waste With Regulated Asbestos Waste

REECo, see Reynolds Electrical \& Engineering Co., Inc.

Reynolds Electrical \& Engineering Co., Inc, 1994. Site Characterization and Monitoring Data From Area 5 Pilot Wells, Nevada Test Site, Nye County, Nevada. DOE/NV/11432-74. U.S. Department of Energy, Nevada Operations Office, Las Vegas, Nevada. 
_, 1993a. Hydrogeologic Data for Existing Excavations at the Area 5 Radioactive Waste Management Site, Nevada Test Site, Nye County, Nevada. DOE/NV11432-40. U.S. Department of Energy, Nevada Operations Office, Las Vegas, Nevada.

— 1993b. Hydrogeologic Data for Science Trench Boreholes at the Area 5 Radioactive Waste Management Site, Nevada Test Site, Nye County, Nevada. DE-AC08-94NV11432. U.S. Department of Energy, Nevada Operations Office, Las Vegas, Nevada.

Sawyer, D. A., R. J. Fleck, M. A. Lanphere, R. G. Warren, and D. E. Broxton, 1990. "Episodic Volcanism in the Southwest Nevada Volcanic Field: New ${ }^{40} \mathrm{Ar} /{ }^{39} \mathrm{Ar}$ Geochronologic Results.” EOS, Vol. 71, American Geophysical Union, p. 1,296.

Snyder, K. E., D. L. Gustafson, H. E. Huckins-Gang, J. J. Miller, and S. E. Rawlinson, 1995. "Surficial Geology and Performance Assessment for a Radioactive Waste Management Facility at the Nevada Test Site.” Waste Management '95 Conference Proceedings, Reference Number 17-12 (CD-ROM). WM Symposia, Inc., Tucson, Arizona.

Stewart, J. H., 1980. Geology of Nevada. Nevada Bureau of Mines and Geology Special Publication 4.

_ 1978. "Basin and Range Structure in Western North America: A Review." Geological Society of America Memoirs.

Winograd, I. J., and W. Thordarson, 1975. Hydrogeologic and Hydrochemical Framework, South-Central Great Basin, Nevada-California, with Special Reference to the Nevada Test Site. Professional Paper 712 C, U.S. Geological Survey, Washington, D.C. 